\title{
Level TE9c of Sima del Elefante (Sierra de Atapuerca, Spain): A comprehensive approach
}

\author{
R. Huguet ${ }^{\text {a, b, c, * }}$, J. Vallverdú ${ }^{\text {a, b, c }}$, X.P. Rodríguez-Álvarez ${ }^{\text {b, a }}$, M. Terradillos-Bernal ${ }^{\mathrm{d}}$, \\ A. Bargalló ${ }^{\text {a, b }}$, A. Lombera-Hermida ${ }^{\text {a, b }}$, L. Menéndez ${ }^{\text {a, b }}$, M. Modesto-Mata ${ }^{\text {e, }}$, \\ J. Van der Made ${ }^{\text {, }}$, M. Soto a, b, H.-A. Blain ${ }^{\text {a, b }}$, N. García h, i, G. Cuenca-Bescós ${ }^{\mathrm{j}}$, \\ G. Gómez-Merino ${ }^{\text {a, b }}$, R. Pérez-Martínez ${ }^{\text {a, b }}$, I. Expósito ${ }^{\text {a, b }}$, E. Allué ${ }^{\text {b, a }}$, J. Rofes ${ }^{\text {k }}$, \\ F. Burjachs ${ }^{a, 1}$, A. Canals ${ }^{\text {b, a }}$, M. Bennàsar ${ }^{a, b}$, C. Nuñez-Lahuerta ${ }^{j}$, \\ J.M. Bermúdez de Castro ${ }^{\text {, }}$ E. Carbonell ${ }^{\text {b, a, c }}$ \\ a IPHES, Institut Català de Paleoecologia Humana i Evolució Social, Campus Sescelades URV (Edifici W3), 43007 Tarragona, Spain \\ b Àrea de Prehistoria, Universitat Rovira i Virgili, Avda. Catalunya 35, 43002 Tarragona, Spain \\ c Unidad asociada al CSIC, Departamento de Paleobiología, Museo Nacional de Ciencias Naturales, Calle José Gutierrez Abascal 2, 28006 Madrid, Spain \\ d Facultad de Humanidades y Ciencias Sociales, Universidad Internacional Isabel I de Castilla, C/Fernán González, $n^{\circ} 76,09003$ Burgos, Spain \\ e Centro Nacional de Investigacioón sobre la Evolució n Humana (CENIEH), Paseo Sierra de Atapuerca 3, 09002 Burgos, Spain \\ ${ }^{\mathrm{f}}$ Equipo Primeros Pobladores de Extremadura, Casa de la Cultura Rodríguez Moñino, Av. Cervantes s/n, 10003 Cáceres, Spain \\ ${ }^{g}$ Museo Nacional de Ciencias Naturales (MNCN), Calle José Gutierrez Abascal 2, 28006 Madrid, Spain \\ ${ }^{\mathrm{h}}$ Departamento de Paleontología, Universidad Complutense de Madrid, Avenida Complutense s/n, 28040 Madrid, Spain \\ ${ }^{i}$ Centro Mixto UCM-ISCIII de Investigación sobre Evolución y Comportamiento Humanos, C/Monforte de Lemos 5, 28029 Madrid, Spain \\ ${ }^{\mathrm{j}}$ Aragosaurus-IUCA, Departamento Ciencias de la Tierra, Universidad de Zaragoza, C/Pedro Cerbuna 12, 50009 Zaragoza, Spain \\ ${ }^{\mathrm{k}}$ Archéozoologie, Archéobotanique: Sociétés, pratiques et environnements (UMR 7209), Sorbonne Universités, Muséum national d'Histoire naturelle, CNRS, \\ CP56, 55 rue Buffon, 75005 Paris, France \\ ${ }^{1}$ ICREA, Institucio Catalana de Recerca i Estudis Avançats, Barcelona, Catalonia, Spain
}

\section{A R T I C L E I N F O}

\section{Article history:}

Available online 11 December 2015

\section{Keywords:}

Early Pleistocene

Europe

Early human occupation

Homo sp.

Mode 1

Subsistence strategies

\begin{abstract}
A B S T R A C T
Level TE9c of the Sima del Elefante site (Sierra de Atapuerca, Spain) is one of the oldest sites with evidence of human occupation in western Europe. We began excavating level TE9c in 2003, and the work there continues today. The studies of the archaeology, palaeontology and geology from this locality have provided an indispensable dataset with which to capture a picture in the scenario of the origin of humans in Europe. Based on these data, we raise and discuss several topics, such as the possible origin of the lineage of the first hominins that inhabited western Europe; their capacity to have active hunting or scavenging abilities; whether their subsistence strategies were successful; and what the environment and habitats where these hominin groups settled was like. The aim of this paper is to present the results and discussions obtained from the research team and to establish the primary features of early human occupations in southwestern Europe. Tentatively, we may conclude, based on the events recorded at TE9c, that the first humans were in the Iberian peninsula at around 1.2 Ma they used the caves of the Sierra de Atapuerca as shelters probably during their hunting activities; the cavities were surrounded by Mediterranean forest, rivers and water ponds, and varied habitats as suggested by the rich and diverse assemblage of fossils of vertebrates (fish, amphibians and reptiles, birds, large and small mammals); where humans possibly caught what they found in the surroundings.
\end{abstract}

(C) 2015 Elsevier Ltd and INQUA. All rights reserved.
* Corresponding author. IPHES, Institut Català de Paleoecologia Humana i Evolució Social, Campus Sescelades URV (Edifici W3), 43007 Tarragona, Spain.

E-mail address: rhuguet@iphes.cat (R. Huguet).

\section{Introduction}

The main aim of this paper is to present the results and interpretations of the study of level TE9c of Sima del Elefante from an interdisciplinary point of view. The assemblage from level TE9c has provided the most data related to the first human occupation of 
Europe. The results obtained from the remains recovered in this level correspond to different fields of research, including geology, chronology, palaeontology, zooarchaeology, taphonomy, palaeobotany, palaeoanthropology and lithic technology. These data have made it possible to reconstruct the paleoenvironment of the area surrounding Sima del Elefante during the formation of level TE9c (Fig. 1).

The Sima del Elefante site (hereafter referred to as TE) is a major cave infill with a stratigraphic succession with a thickness of $25 \mathrm{~m}$ and a width of 15 in the exposed section, divided into 16 litho-stratigraphic units, called TE7 to TE21, from bottom to top (Rosas et al., 2001, 2004, 2006). A palaeomagnetic analysis has detected a polarity change at the base of unit TE17. Thus, the sediments below this unit, from TE7 to TE16, have reversed polarity and have been assigned to the Matuyama chron (>780 ka) (Rosas et al., 2001; Parés et al., 2006). According to Arnold and Demuro (2015) the corresponding weighted mean TT-OSL (Thermally transferred optically stimulated luminescence) ages for units TE16 and TE17 at Sima del Elefante are $890 \pm 70 \mathrm{ka}$ and $789 \pm 47 \mathrm{ka}$, respectively.

More recent units (TE18-TE19) containing archaeological and palaeontological records have been attributed to the second half of the Middle Pleistocene, around 250-350 ka (OIS 9-8), on the basis

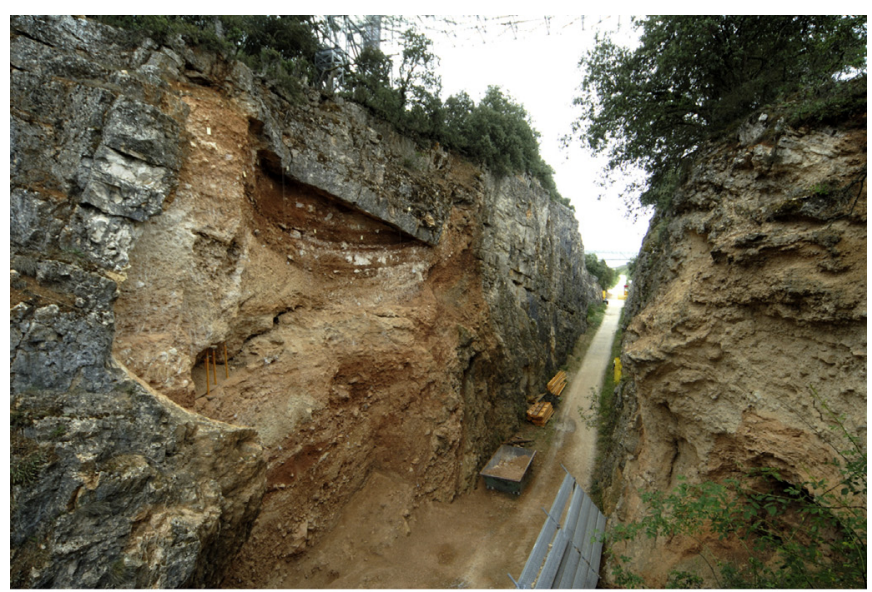

a.

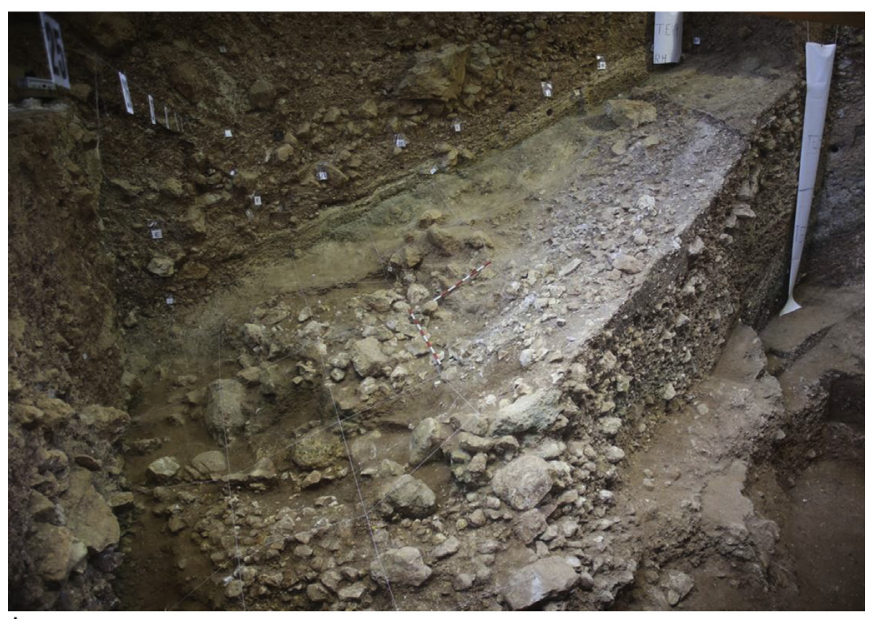

b.

Fig. 1. a. View of Sima del Elefante cave. b. View of surface of level TE9c of Sima del Elefante in 2014. of a biochronological analysis (Rosas et al., 2006; López-García et al., 2011). A uranium series (U/Th) analysis of the stalagmitic crust from the roof of level TE18 has yielded two dates, $307 \pm 19 \mathrm{ka}$ and $255 \pm 12 \mathrm{ka}$ (Bischoff, pers. comm.). These results suggest that level TE18 was formed during MIS 9 and 7, and that the chronology of TE19 is more recent than 255 ka (de Lombera-Hermida et al., 2015).

The lower levels (TE7-TE14) of the sedimentary infill constitute the Early Pleistocene stratigraphic sequence with the longest archaeo-palaeontological record in Europe. This has allowed us to propose a diachronic study in relation to the different faunal and botanical taxa identified throughout the stratigraphic succession as well as to the human groups that lived near the site about 1 million years ago. However, to carry out a diachronic study on the Early Pleistocene at Sima del Elefante, each archaeopalaeontological level documented must first be characterized (Fig. 2).

\section{Unit 9}

\subsection{Geological settings}

The sedimentary facies of the Sima del Elefante are described in detail in Rosas et al. (2001, 2004, 2006). Unit TE9 has been described as consisting of brown mud with subangular blocks in beds markedly sloping to the north (38 $8^{\circ}$ (Parés et al., 2006). In level TE9c, limestone blocks exhibit developed weathering cortices, and the decomposition of some of these blocks sometimes affect the fossils that were in contact with them.

Unit TE9 contains three subunits TE9c, TE9b and TE9a (from bottom to top).

Subunit 9c is a finely stratified stratum of $1 \mathrm{~m}$ thick. It is a bedset of mud and fine gravelly mud lithology. There are 2 sedimentary facies:

- Crystalline yellow and red, brown and black mud in finely stratified beds. The beds are deformed, massive and laminated.

- Crystalline yellow and gravelly mud in stratified beds. Pebble limestone gravels are polymodal (sub-rounded and altered/ weathered) within massive laminated and mud supported beds. These mud supported beds are microstratified and the mud is reddish yellow, reddish brown and pinkish white (5YR).

Subunit $9 \mathrm{~b}$ is a stratified bedset of fine gravels and reddish brown sandy mud. The fine gravels are sandy mud supported. Subunit 9a is a coarse bed consisting of limestone breccia. The blocks and gravels are clast and reddish yellow muddy sand supported (Fig. 3).

The lithostratigraphy of level TE9c defined in this study is consistent with other analogous units of the sedimentary successions of the Trinchera del Ferrocarril. The composition formed by limestone, with developed weathering cortex and stratified reddish yellow, reddish brown and pinkish white (5YR), muds or gravelly muds, illustrates similar lithologies as those in (1) unit GIIA, especially below the vertical passage (shaft) of Trinchera Norte in the Trinchera Galeria site, and (2) the deposits of units TD8-9 and TD9 near the cave wall south of Trinchera Dolina cave. The truncated terminations of these lithostratigraphic units suggest that they are part of the sedimentary infill of subsidence or suffusion dolines (shakeholes) (Lowe and Waltham, 1995). The origin of these shakeholes in the Trinchera del Ferrocarril cave entrances is likely related to the aperture and sedimentary infill of conduits that connect the second and third floor cave passages of the karst system of the Sierra de Atapuerca. 


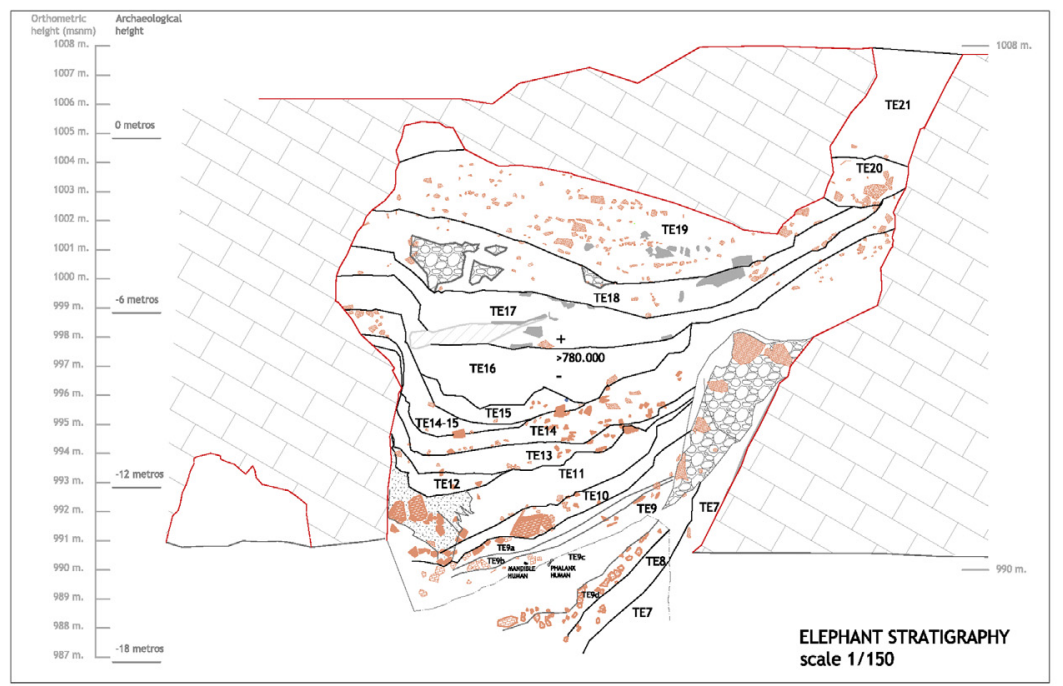

\begin{tabular}{|c|c|c|}
\hline Samples & Label of sample & Reference \\
\hline \multicolumn{3}{|c|}{ Pollen samples } \\
\hline $1-1501 \mathrm{~cm}$ & ATA'08-TE'09C-K29-105 & Unpublished (Fig. 11 in this paper) \\
\hline $2-1493 \mathrm{~cm}$ & ATA'08-TE'09C-K29-106 & Unpublished (Fig. 11 in this paper) \\
\hline $3-1486 \mathrm{~cm}$ & ATA'08-TE'09C -K29-107 & Unpublished (Fig. 11 in this paper) \\
\hline $4-1472 \mathrm{~cm}$ & ATA'08-TE'09C-K29-108 & Unpublished (Fig. 11 in this paper) \\
\hline $5-1464 \mathrm{~cm}$ & ATA'08-TE'09C-K29-109 & Unpublished (Fig. 11 in this paper) \\
\hline $6-1450 \mathrm{~cm}$ & ATA'08-TE'09C -K29-110 & Unpublished (Fig. 11 in this paper) \\
\hline $7-1442 \mathrm{~cm}$ & ATA'08-TE'09C-K29-111 & Unpublished (Fig. 11 in this paper) \\
\hline $8-1431 \mathrm{~cm}$ & ATA'08-TE'09C -K29-112 & Unpublished (Fig. 11 in this paper) \\
\hline $9-1415 \mathrm{~cm}$ & ATA'08-TE'09C- J31-8 & Unpublished (Fig. 11 in this paper) \\
\hline $10-1408 \mathrm{~cm}$ & ATA'08-TE'09C -J31-7 & Unpublished (Fig. 11 in this paper) \\
\hline $11-1396 \mathrm{~cm}$ & ATA'08-TE'09C-J31-6 & Unpublished (Fig. 11 in this paper) \\
\hline $12-1387 \mathrm{~cm}$ & ATA'08-TE'09C -J31-5 & Unpublished (Fig. 11 in this paper) \\
\hline $13-1375 \mathrm{~cm}$ & ATA'08-TE'09C - J31-4 & Unpublished (Fig. 11 in this paper) \\
\hline \multicolumn{3}{|c|}{ Cosmogenics sample } \\
\hline $\begin{array}{c}\text { C-TEgb }- \text { T1. } \quad 1.22 \pm 0.14 \\
(0.16) \text { Myr Burial age }\end{array}$ & ATA'05-TE9b-J31-1 & Carbonell et al. 2008 \\
\hline \multicolumn{3}{|c|}{ Human remains } \\
\hline ATE'09-1 Mandible & АТА'07-TE9c-131-19 & Carbonell et al. 2008 \\
\hline ATE'09-2 Phalanx & ATA'08-TE9C-128-18 & Lorenzo et al. 2015 \\
\hline
\end{tabular}

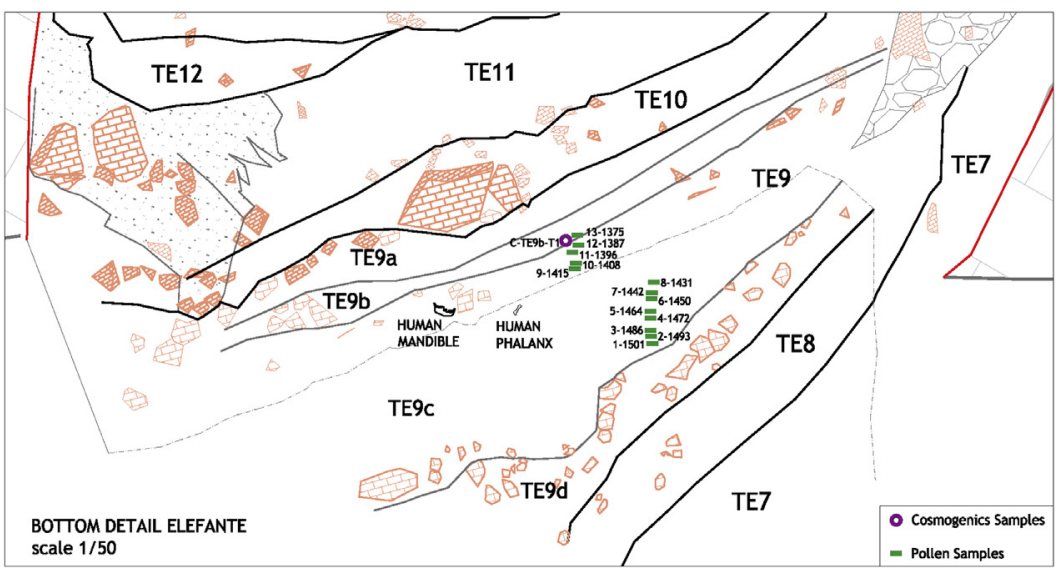

Fig. 2. The topographic profile of Sima del Elefante site with the location of pollen samples, human remains and cosmogenics samples from TE9c.

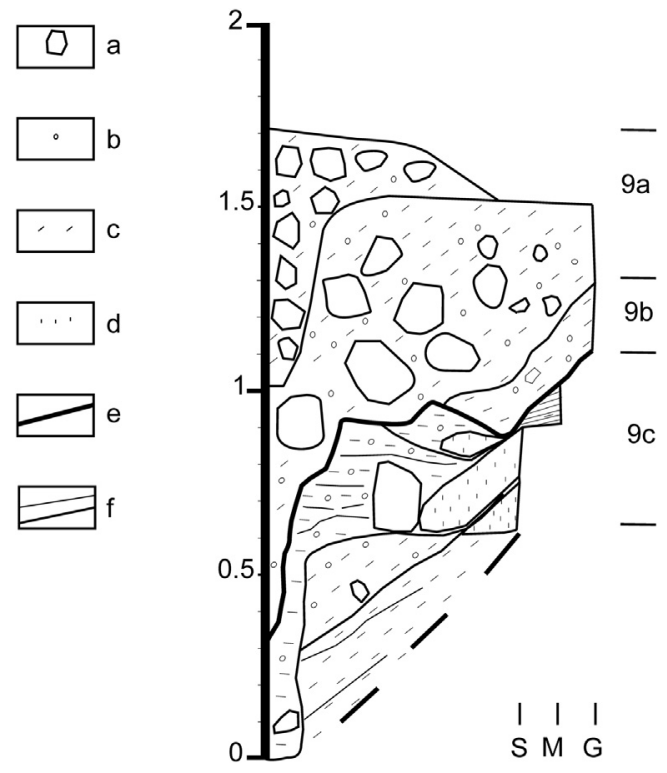

Fig. 3. Lithofacies of unit TE9. Legend: a, limestone blocks and coarse gravels; $\mathbf{b}$, fine gravels; c, mud; d, crystallitic and weathered calcite; e, unconformity (erosive); f, paraconformities and diastemes. S: speleothems; M: mud; G: Gravels.
TE9 contains a major stratigraphic bed marker in subunit TE9c. The limestone gravels and blocks with developed weathering cortex point to major episodes of non-deposition and erosion (hiatuses with stratigraphic lacunae) (Campy, 1986). The erosive truncations (entrenchment) observed in subunits $9 \mathrm{c}$ and $9 \mathrm{~b}$ near the northern wall of the Trinchera Elefante indicate the aperture of the passage between the second and third floors of the endokarst system. Subunit 9a testifies the spatial migration of the entrenchment and signifies the infill of the conduit that connected the second and third floors of the endokarst system.

The sedimentary succession of the shakehole of TE9c contains a facies association and a stratification pattern similar to the deposits

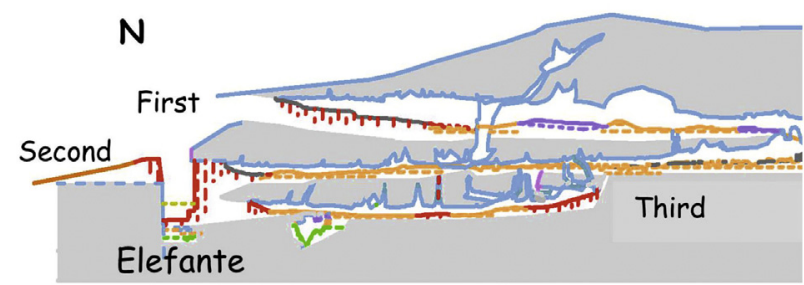

Fig. 4. Detail of longitudinal profiles of the caves of the Sierra de Atapuerca (Ortega et al., 2014). We can see all three endokarstic levels developed and their connection. 


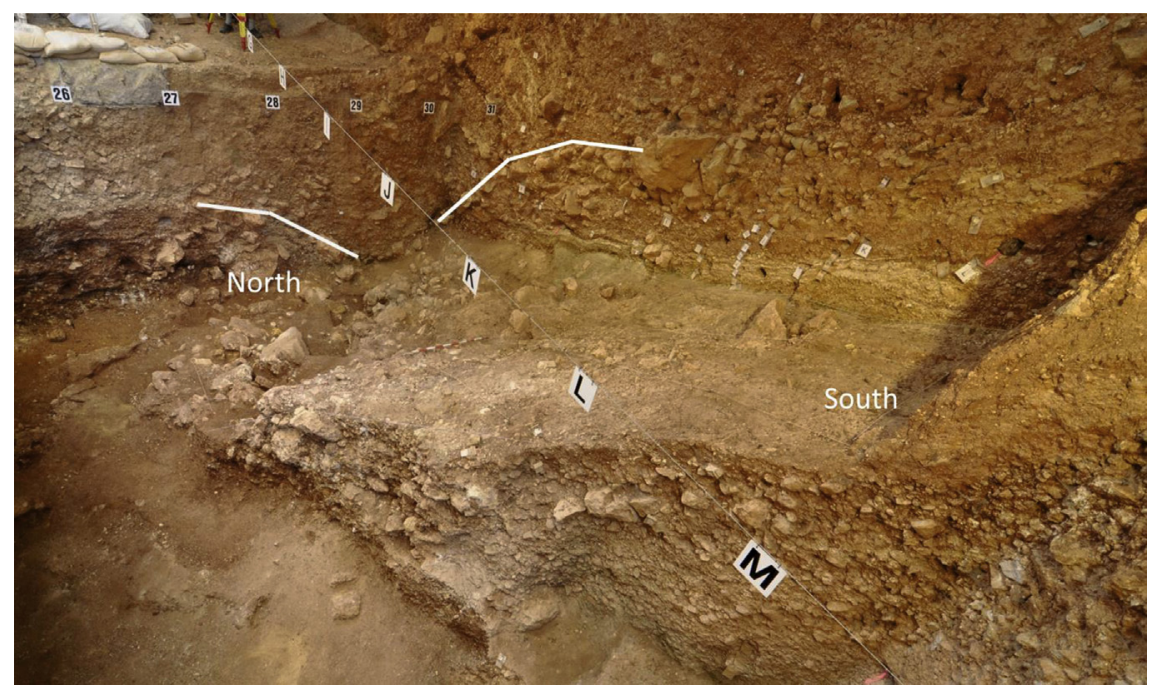

Fig. 5. View of the lower levels of Sima del Elefante slope and its deformation and collapse in northern part of cave.

of TD8-9 and TD9 at Trinchera Dolina and GIIA at Trinchera Galeria. The beds are made up of weathered limestone blocks and gravel fills with decalcified muds or black, brown, red and yellow gravelly mud. These sedimentary successions are microstratified in fine beds and represent the sediments of the distal zone from the entrance point of the deposits.

According to Parés et al. (2006) the inclination of the strata was sedimentary in origin, and therefore the slope observed in these deposits was a primary feature (paleodepositional surface). However, another hypothesis maintains that the inclination of TE9c took place as a result of the collapse of the lower karst galleries. The Sima del Elefante belongs to the second endokarstic level developed in the Sierra de Atapuerca karst system. When the third endokarst level was formed under the Sima del Elefante level, the lower stratigraphical units collapsed (Ortega et al., 2014) (Fig. 4).

Today, the lower levels of Sima del Elefante slope from south to north, but this is caused by deformation and the collapse of sediment in the northern part of cave. Thus, probably, the original inclination of the strata was oriented from north to south. The proximal facies, located at the north end, are coarser than the distal facies, whose sediments have been diminished to fine silt, and are laminated in some cases. The size of the facies and the deformation observed by the collapse of the sediments suggests that preserved sediments entered the cavity by a talus cone orientated from north to south. The original entrance to the cavity during the Early Pleistocene was most likely more of a fissure configuration than a large cave entrance (Rosas et al., 2004) (Fig. 5).

\section{Level 9c}

In 2003 we began excavating level TE9c over a surface area of approximately 12 square metres. The excavation of this level is still under way today across a surface area that has increased to about 30 square metres. TE9c has a maximum thickness of $1 \mathrm{~m}$. To date, we have documented the coordinates of over 6000 archaeopalaeontological remains and recovered over 15,000 remains by washing and sieving the sediment materials acquired from the excavation. The latter consist mainly of small vertebrate and fish remains.

\subsection{Chronology}

Level TE9c has been dated to the Early Pleistocene around 1.3-1.1 Ma on a combination of palaeomagnetism, cosmogenic nuclides and biostratigraphic markers. According to biochronological data related to small mammals (Allophaiomys lavocati biozone) and large mammals (Epi-Villafranchian fauna (Bourdier, 1961), sensu (Kahlke, 2007)) (the lower units (TE14-TE7) of Sima del Elefante may comprise the time interval between 1.5 and $1.1 \mathrm{Ma}$ (Laplana and Cuenca-Bescós, 2000; Cuenca-Bescós and García, 2007; García et al., 2008; Cuenca-Bescós et al., 2010, 2013).

The small mammals recovered correspond to an interval biozone defined by the concurrent range zone of $A$. lavocati, A. nutiensis, A. burgondiae and Castillomys rivas and it characterizes the pre-Jaramillo faunas. This interval biozone is characterized by an early differentiation and large diversity of the species of Allophaiomys before the Jaramillo subchron (CuencaBescós et al., 2010, 2015). The carnivore assemblage of the lower levels (TE7-TE14) of Sima del Elefante is also very rich and corresponds to Epi-Villafranchian taxa, as indicated by the Pannonictis cf. nestii remains recovered (García and Howell, 2008; García et al., 2008). This taxon occurs at some Plio-Pleistocene sites in Eurasia slightly before 2.6 Ma and up until the EpiVillafranchian (between 1.3 and 0.9 Ma) (García et al., 2008; Colombero et al., 2012).

Cosmogenic ${ }^{26} \mathrm{Al} /{ }^{10} \mathrm{Be}$ (Granger et al., 2001; Stock et al., 2004) burial dating suggests a date of ca. 1.2-1.1 Ma. We collected two samples from the study area. The first sample was collected from layer $9 \mathrm{~b}$, in the central part of unit TE9. This sample was collected about $40 \mathrm{~cm}$ above the artefacts and the hominin fossils in layer TE9c, and has a burial age of 1.2260.16 Ma. A second sample was collected from unit TE7, which contains a similar microfaunal assemblage to unit TE9. This second sample has a burial of 1.1360.18 Ma, indistinguishable from that of layer TE9b (Carbonell et al., 2008).

\subsection{Archaeo-paleontological record}

The remains recovered in TE9c can be divided into three main groups: faunal remains, stone tools and human fossils. The faunal remains are the most abundant group. 


\subsubsection{Faunal remains}

A remarkable diversity of faunal taxa, including amphibians, reptiles, fish and birds, and large and small mammals has been sp., Carduelis chloris, Pica pica, Corvus antecorax, Corvus frugilegus (Sánchez Marco, 2002, 2004; Cuenca-Bescós et al., 2015) (Table 1).

Table 1

List of vertebrates identified in level TE9c.

\begin{tabular}{|c|c|}
\hline Primates & Homo sp., Cercopithecidae \\
\hline Proboscidea & Mammuthus sp. \\
\hline Herbivores & Sus sp.; Bison menneri; Dama vallonnetensis, Eucladoceros giulii, Stephanorinus sp., Equus altidens \\
\hline Carnivores & $\begin{array}{l}\text { Panthera gombaszoegensis, Lynx sp. Pannonictis cf. nestii, cf. Baranogale antiqua, Mustela cf. palerminea/praenivalis, Canis cf mosbachensis/arnensis, } \\
\text { Vulpes cf. alopecoides, Ursus cf. dolinensis }\end{array}$ \\
\hline Osteichthyes & Salmo sp., Leuciscus sp. \\
\hline Anura & Alytes obstetricans, Pelobates cultripes, Pelodytes punctatus, Bufo bufo, Bufo calamita, Hyla arborea, Rana sp., cf. Pelophylax. \\
\hline Caudata & Salamandra salamandra, Triturus cf. Marmoratus \\
\hline Squamata & Anguis fragilis, Natrix cf. natrix, Natrix cf. maura, Coronella cf. girondica, Vipera sp., Lacerta genus incertae sedis \\
\hline Aves & $\begin{array}{l}\text { Galliformes indet., Corvus antecorax, Corvus frugileus, Columba livia/olea, Haliaeetus albicilla, Falco cf.tinnunculus, Carduelis chloris, } \\
\text { Remiz sp., Certhia sp., Turdus sp., Pica pica, Perdix paleoperdix, Passeriformes indet. }\end{array}$ \\
\hline Chiroptera & Myotis gr. myotis/blythii, Miniopterus schreibersii, Rhinolophus ferrumequinum, Rhinolophus gr. euryale/mehelyi, Pipistrellus sp., Chiroptera indet. \\
\hline Eulipotyphla & $\begin{array}{l}\text { Sorex gr. runtonensis-subaraneus, Sorex margaritodon, Asoriculus gibberodon, Beremendia fissidens, Crocidura kornfeldi, Galemys cf. kormosi, } \\
\text { Talpa cf. europaea, Erinaceus cf. praeglacialis }\end{array}$ \\
\hline Rodentia & $\begin{array}{l}\text { Sciurus sp., Castillomys rivas, Apodemus sp, Eliomys sp., Allophaiomys lavocati, A. burgondiae, A. nutiensis, Arvicola jacobaeus, Ungaromys nanus, } \\
\text { Pliomys cf. simplicior, Castor sp. }\end{array}$ \\
\hline Lagomorpha & Lepus terraerubrae, Oryctolagus lacosti \\
\hline
\end{tabular}

documented in level TE9c. The amphibians and reptiles of this assemblage comprise at least 19 taxa (represented by roughly 2110 bone fossil remains): Triturus cf. marmoratus, Alytes obstetricans, Pelobates cultripes, Pelodytes punctatus, Bufo bufo, Bufo calamita, Rana sp., cf. Pelophylax, Testudo hermanni, Emys cf. orbicularis, Lacerta genus incertae sedis, small-sized indeterminate lacertids, Coronella cf. girondica and Vipera sp. (Blain et al., 2010; Blasco et al., 2011). Only two taxa of fish have been identified in this level: Salmo sp. and Leuciscus sp. (Cuenca-Bescós et al., 2015).

The fossil record of level TE9c is striking for the high number of bird remains from different taxa that have been recovered, such as Haliaeetus albicilla, Falco cf, tinnunculus, Galliformes indet., Perdix paleoperdix, Columba livia/oenas, Passeriformes indet., Certhia sp., Turdidae indet., Turdus sp., Remiz
There are at least 25 small mammal taxa: Sorex gr. runtonensissubaraneus, Sorex margaritodon, Asoriculus gibberodon, Beremendia fissidens, Crocidura kornfeldi, Galemys cf. kormosi, Talpa cf. europaea, Erinaceus cf. praeglacialis, Oryctolagus cf. lacosti, Lepus cf. terraerubrae, Miniopterus schreibersii, Myotis sp., Rhinolophus sp., Chiroptera spp., Sciurus sp., C. rivas, Apodemus aff. sylvaticus, A. lavocati, A. burgondiae, A. nutiensis, Arvicola jacobaeus, Ungaromys nanus, Pliomys cf. simplicior, Eliomys sp. and Castor sp. The presence of A. lavocati, A. nutiensis, A. burgondiae and C. rivas is particularly noteworthy, as they provide relevant chronological information (Rofes and Cuenca-Bescós, 2006, 2009, 2011, 2013; Cuenca-Bescós et al., 2010, 2013, 2015; Rofes et al., 2014; Galán et al., 2015) (Figs. 6 and 7).

The large mammal remains recovered are less abundant than those of the small mammals, some Cercopithecidae remains have

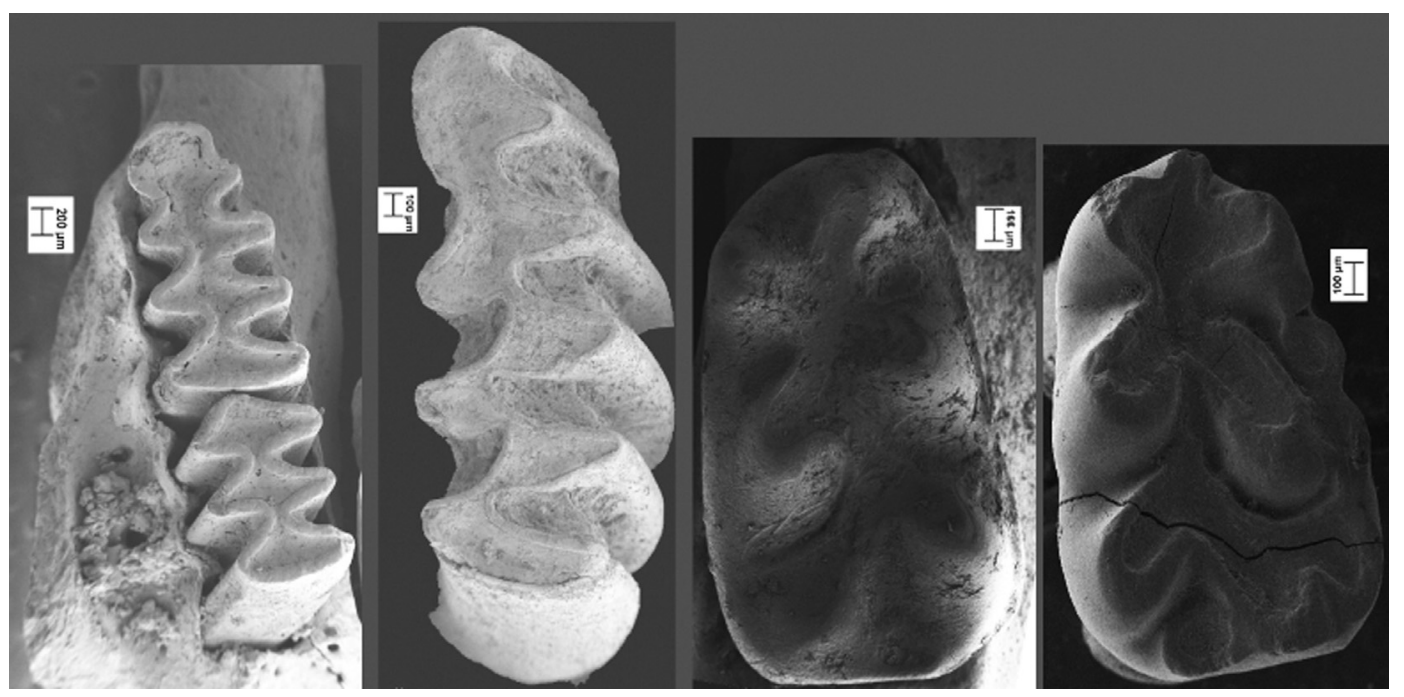

Fig. 6. Small mammals from TE9, from left to right: Ungaromys sp., Allophaiomys lavocati, Castillomys rivas, Apodemus sp. 

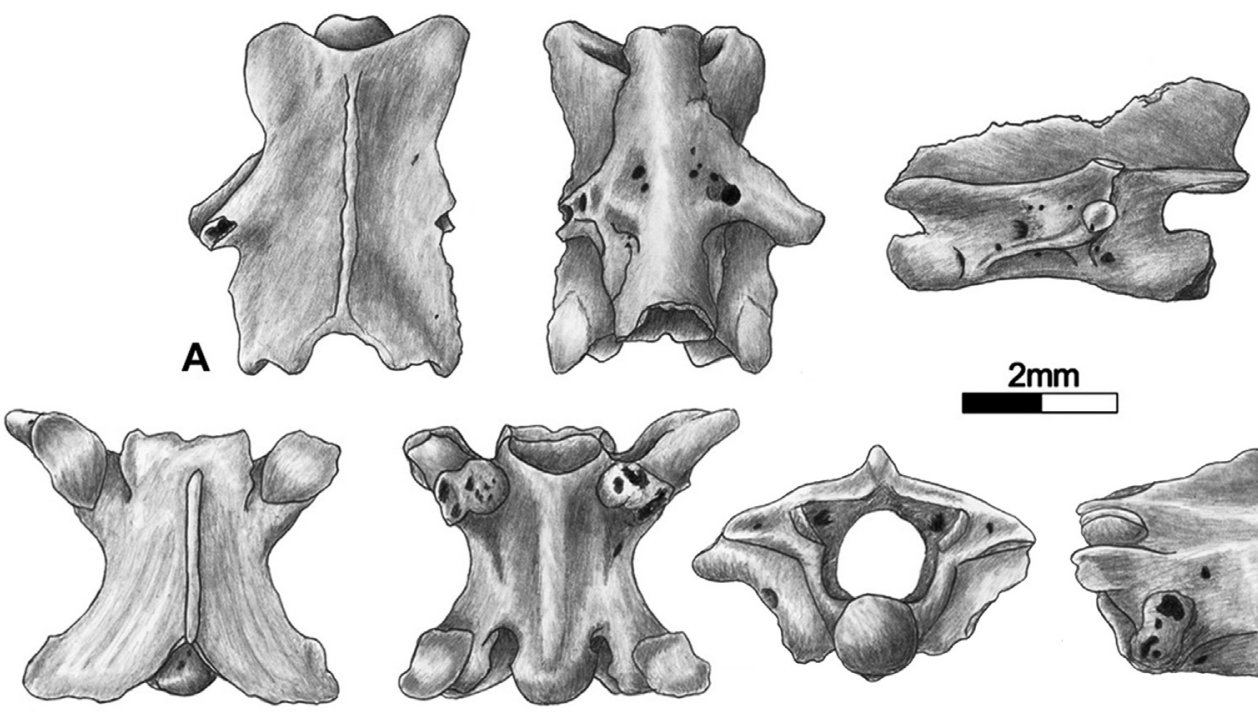

B
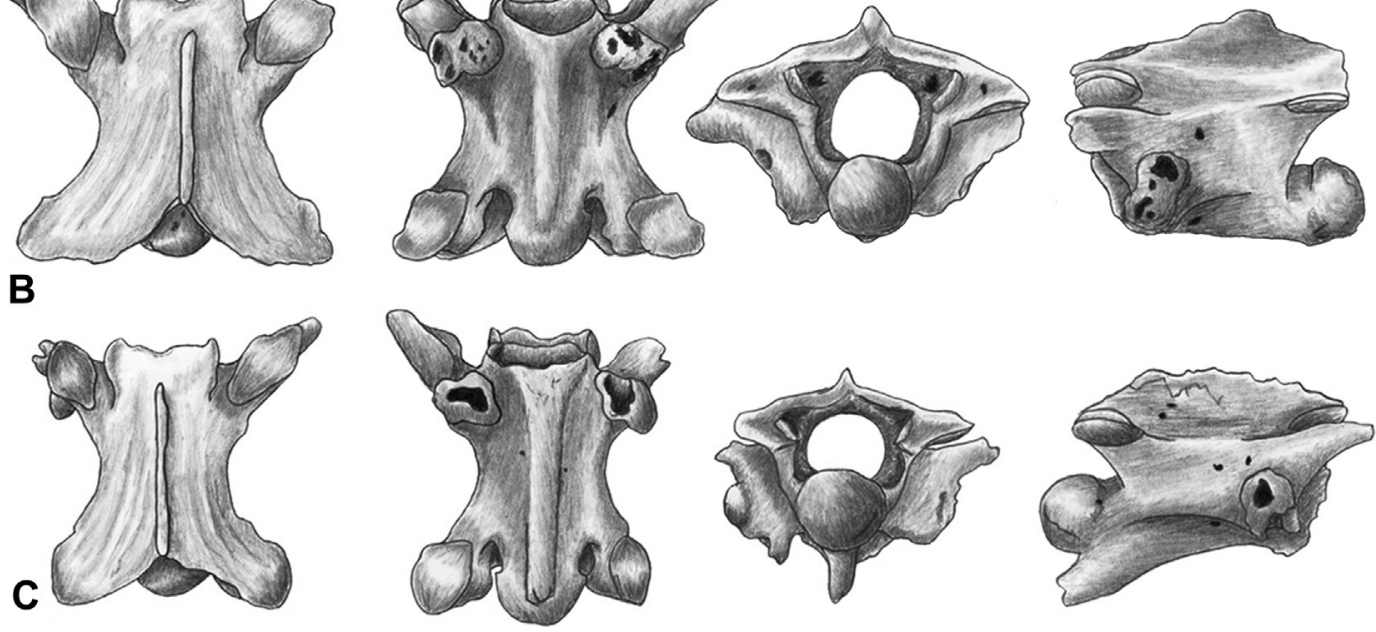

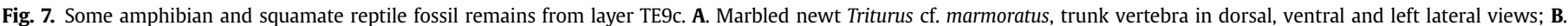

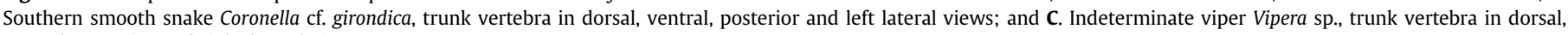
ventral, posterior and right lateral views.

been recovered in this assemblage as well. However, species diversity is high for carnivores: Panthera gombaszoegensis, Lynx sp., Pannonictis cf. nestii, cf. Baranogale antiqua, Mustela cf. palerminea/ praenivalis, Canis cf. mosbachensis/arnensis, Vulpes cf. alopecoides, Ursus cf. dolinensis and ungulates: Mammuthus sp., Sus sp.; Bison cf. menneri; Dama vallonnetensis, Eucladoceros giulii, Stephanorhinus sp., Equus altidens (Rosas et al., 2001, 2004; Van der Made, 2003; Cuenca-Bescós and García, 2007; García et al., 2008; Van der Made, 2013) (Fig. 8).

\subsubsection{Human remains}

Level TE9c became internationally known in 2007 due to the discovery of a hominin fossil, specifically a jaw of an adult hominin, which was the oldest human fossil recovered in western Europe (Carbonell et al., 2008).

Initially, this mandible was provisionally assigned to Homo antecessor (Bermúdez de Castro et al., 2010), although a detailed morphological comparative study of the hominin mandible ATE9-1 conducted by Bermúdez de Castro et al. (2011) revealed some primitive Homo traits on the external aspect of the symphysis and the dentition that are shared with early African Homo and the Dmanisi hominins. In contrast, other mandibular traits on the internal aspect of the symphysis are derived from early African Homo. Therefore, these authors, in the absence of any additional evidence, prefer not to include specimen ATE9-1 in any named taxon and refer to it as Homo sp.
The analysis of this mandible shows some pathological signs which can be explained by compensatory eruption. Despite the severity of these lesions, occlusion was possible, so it was unlikely that the lesions seriously impacted the individual's daily life (Martinón-Torres et al., 2011).

Besides the jaw, a fifth proximal hand phalanx (ATE9-2) belonging to an adult individual of over 16 years old has also been recovered (Lorenzo et al., 2015). According to these authors the morphological and metrical analyses of the phalanx ATE9-2 indicate that there are no essential differences between it and comparator fossil specimens for the genus Homo (Sima de Huesos and Neanderthals specimens) after 1.3 Ma. Thus, the age of level TE9 at Sima del Elefante and the morphometrical studies of ATE9-2 suggest that the morphology of the hand could have remained stable over the last 1.2 Ma (Fig. 9).

\subsubsection{Stone tools}

The lithic assemblage found in TE9c is made up of 33 artefacts. The raw materials used are Cretaceous limestone of allochthonous origin ( $n=17)$, Cretaceous and Neogene chert $(n=14)$, and quartz $(\mathrm{n}=2)$ (Table 3$)$. This lithic assemblage is nearly entirely made from different varieties of chert and Cretaceous limestone, the latter possibly related to outcrops of Cretaceous chert. All of the raw materials (Cretaceous and Neogene chert, mainly) are today available within an immediate radius of no more than $2 \mathrm{~km}$, which indicates recurrent access to the lithic resources located in the primary procurement zone (0-3 km) (Féblot-Augustins, 1999). 


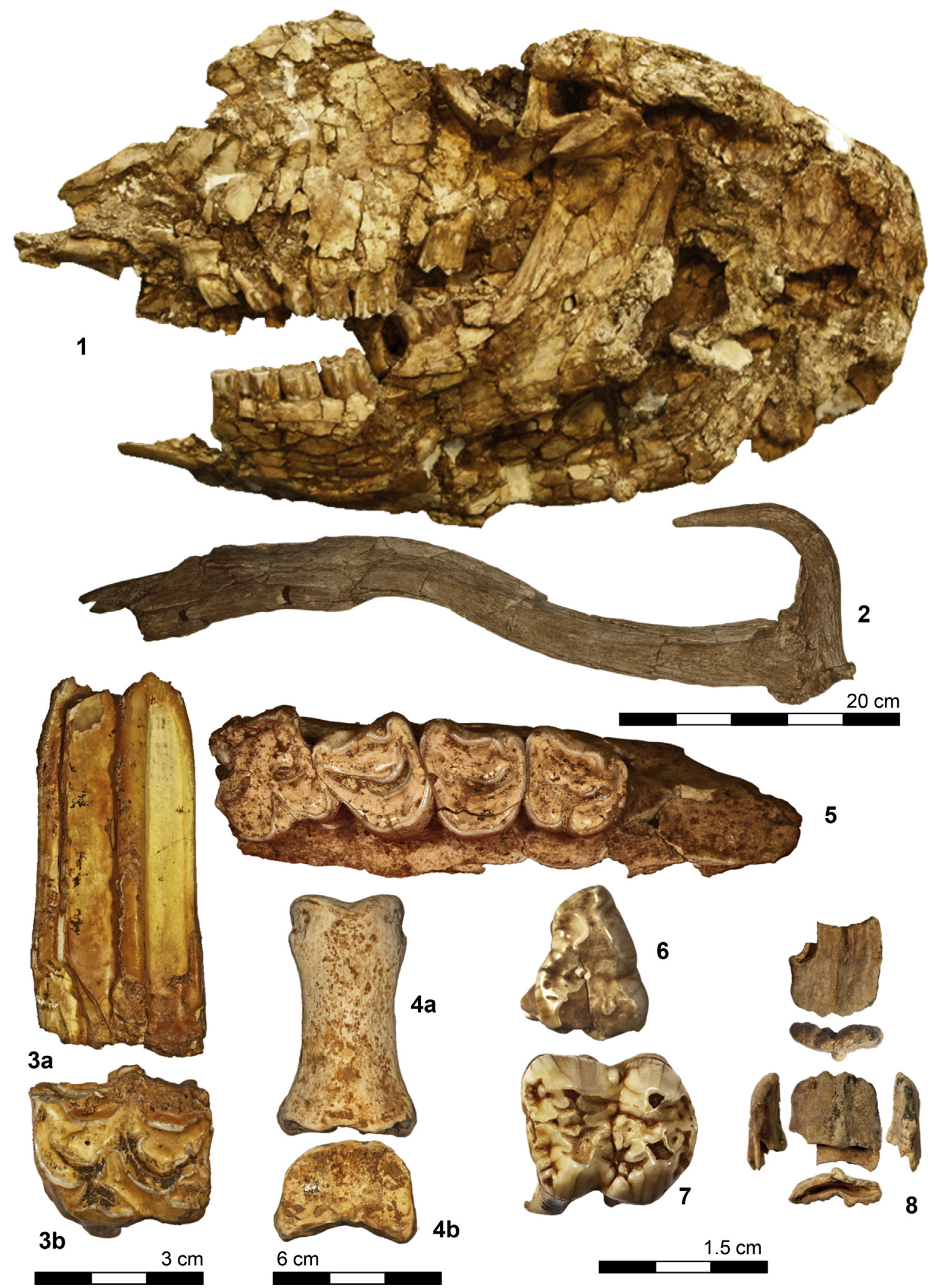

Fig. 8. The ungulates from Atapuerca TE9: 1) Bison cf. menneri: Ata11, TE9c, F-31, 6 - skull, left side. 2) Dama: Ata08, TE9c, J-28, 50 - let antler, medial view. 3) Equus altidens: Ata12, TE9c, H-27, 20 - left P3/4: a) buccal and b) occlusal views. 4) Equus altidens: Ata2000, TE9c, L-30, 1 - left first phalanx of the third digit: a) dorsal, and b) proximal views. 5) Eucladoceros cf. giulii: Ata03, TE9c, K-30, 1 - right maxilla with $\mathrm{P}^{2}-\mathrm{M}^{1}$, occlusal view. 6-7) Sus sp. Ata13, TE9c, H-27, 31 - left $\mathrm{D}^{3}$ (6) and left $\mathrm{D}^{4}$ (7). 8) Mammuthus sp.: Ata09, TE9c, J31,12 - plate of a milk tooth, various views. Fig. 1 not to scale, figure to the $20 \mathrm{~cm}$ scale, Fig. 3 and 5 to the $6 \mathrm{~cm} \mathrm{scale,} \mathrm{Fig.} 4$ to the $3 \mathrm{~cm}$ scale, and Figs. $6-8$ to the $1.5 \mathrm{~cm} \mathrm{scale.}$ 


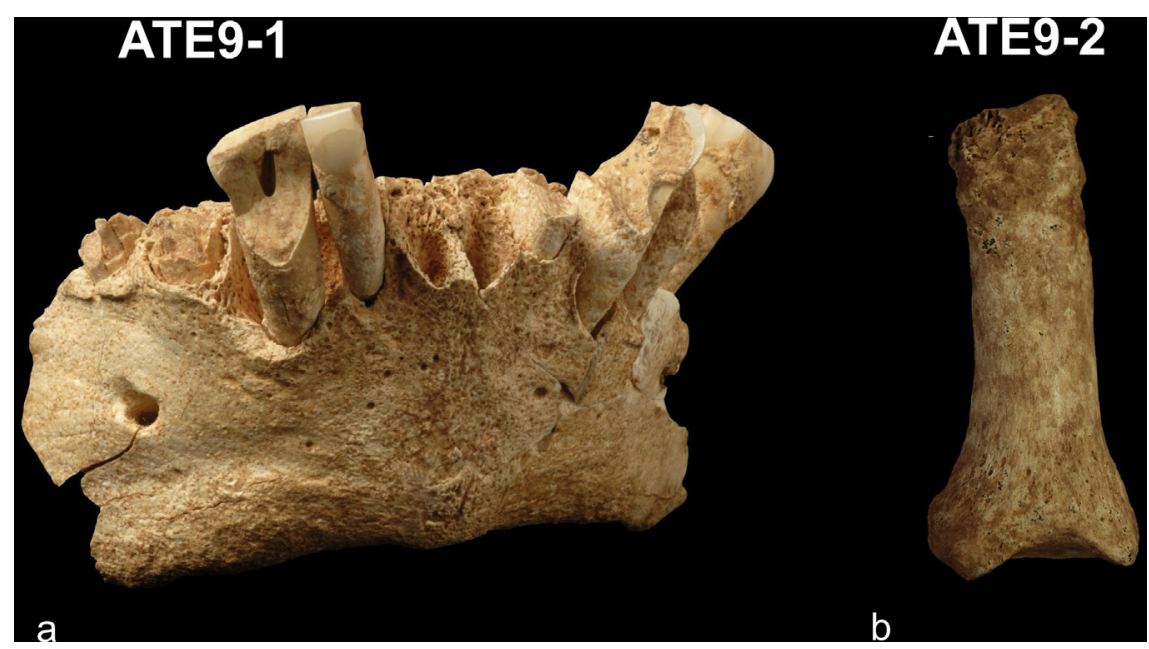

Fig. 9. Human remains from TE9c. a. A jaw of an adult hominin (ATE9-1). b. A fifth proximal hand phalanx (ATE9-2).

Table 2

Raw material groups and lithic categories of the artefacts recovered from TE9c.

\begin{tabular}{|c|c|c|c|c|c|c|c|c|c|}
\hline & Fragmented pebbles & Cores on pebble & Flakes & Broken flakes & Fragments of flakes & Fragments & Indet & Total & $\%$ \\
\hline & Bnc & BN1GE & $\mathrm{BP}$ & $\mathrm{BPF}$ & FBP & Frag & Indet & & \\
\hline Neogene Chert & - & - & 1 & - & - & 1 & 6 & 8 & 24.24 \\
\hline Cretaceous Chert & - & 1 & 2 & - & 2 & - & - & 5 & 15.15 \\
\hline Chert & - & - & - & - & - & - & 1 & 1 & 3.03 \\
\hline Quartz & 1 & - & - & - & - & 1 & - & 2 & 6.06 \\
\hline Cretaceous Limestone & - & 2 & 4 & 6 & 3 & 2 & - & 17 & 51.52 \\
\hline Total & 1 & 3 & 7 & 6 & 5 & 4 & 7 & 33 & \\
\hline$\%$ & 3.03 & 9.09 & 21.21 & 18.18 & 15.15 & 12.12 & 21.21 & 100 & \\
\hline
\end{tabular}

Knapping products (flakes, flake fragments, etc.) are the best represented lithic category in this assemblage $(n=18)$. Only two cores and one core fragment were recovered from level TE9c. The cores exhibit short reduction sequences based on longitudinal removals (1-4 scars), taking advantage of natural or previously knapped surfaces as striking platforms, and showing little complexity in the reduction sequences. Accordingly, the flakes have flat, thick butts, and longitudinal removals on their dorsal faces. The knapping products have varied morphologies with dihedral cutting edges. Most of the lithic implements are small. On the basis of its technical features, the lithic assemblage from TE9c has been ascribed to the Mode 1 techno-complex (de LomberaHermida et al., 2015). Although unit TE9 yielded the most

Table 3

Taxa determinated in TE9c level of Sima del Elefante. The table shows the NISP and percentage of identified.

\begin{tabular}{lrl}
\hline & NISP & $\%$ \\
\hline Aves & 3821 & 52.8 \\
Leporidae & 453 & 6.3 \\
Carnivores & 338 & 4.7 \\
Ungulates & 323 & 4.5 \\
Primates & 11 & 0.1 \\
Indet. & 2286 & 31.6 \\
Total & 7231 & 100 \\
\hline
\end{tabular}

significant lithic assemblage of the Lower Pleistocene units of Sima del Elefante, the absence of shaped tools in this unit is remarkable. Thus, the knapping sequences focused on obtaining flakes with suitable cutting edges rather than on shaping tools. The occurrence of a core fragment and a flake that seem to belong to the same nodule of Cretaceous chert prove that some knapping may have been carried out on site or close to the entrance of the cave (Ollé et al., 2013; de Lombera-Hermida et al., 2015) (Fig. 10, Table 2).

\subsection{Taphonomic settings}

The taphonomic studies of the remains and of the origin of the accumulation of fossils recovered in level TE9c are still in progress. However, some preliminary results can be discussed here (Table 3).

The faunal remains recovered in level TE9c have been grouped into three different sets according to their taphonomic characteristics and the origin of their accumulation. The first group is the largest and it is made up of the remains of small animals (birds and lagomorphs). Birds represent 53\% of the total faunal remains recovered in this level.

Among the bird taxa identified in TE9c, small birds such as Carduelis cholis, Certhia sp., and Remiz sp. have been documented, along with diurnal raptors such as Haliaeetus albicilla and Falco tinnunculus and rock-dwelling birds such as Corvus antecorax and Columba livia/oenas. These latter taxa are the most abundant (Table 4). 


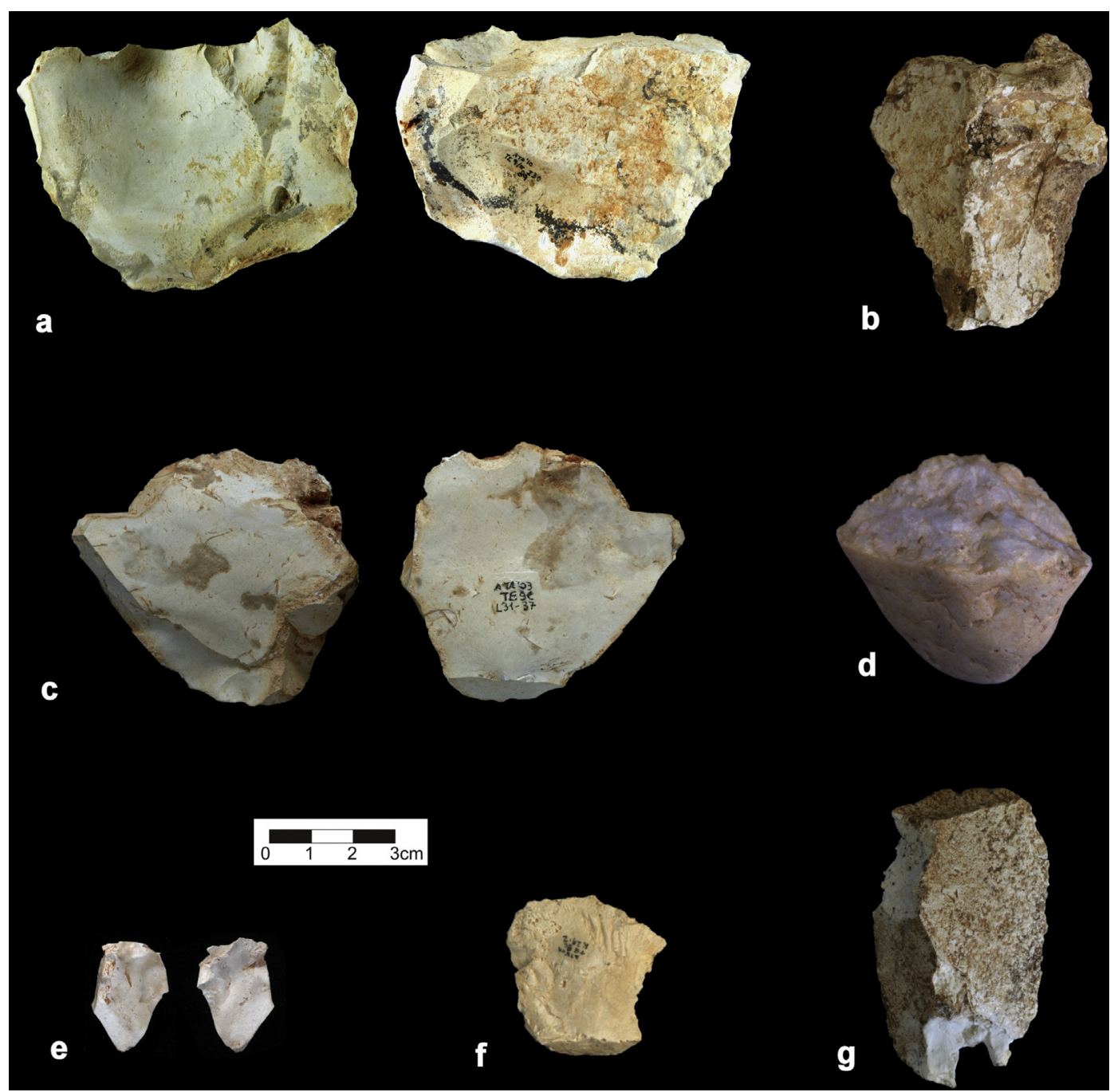

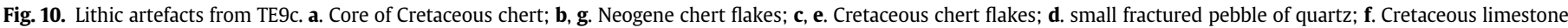
flake.

Table 4

Number Identified of Specimens (NISP) of bird remains.

\begin{tabular}{lr}
\hline Aves & NISP \\
\hline Skull & 9 \\
Scapula & 68 \\
Coracoid & 165 \\
Clavicle & 2 \\
Vertebra & 92 \\
Ribs & 8 \\
Sternum & 6 \\
Humerus & 281 \\
Radius & 56 \\
Ulna & 511 \\
Carpomtc. & 232 \\
Coxae & 13 \\
Femur & 260 \\
Tibiotarsus & 322 \\
Fibula & 10 \\
Tarsomtt. & 269 \\
Carpal/tarsal & 18 \\
Phalange & 198 \\
Long bone & 493 \\
Flat bone & 28 \\
Indet. & 780 \\
Total & 3821 \\
\hline
\end{tabular}

All bird skeletal elements have been documented, although the remains of the extremities are the most common. The scarcity of cranial remains is probably due to the fact that these elements have a very thin bony wall which negatively affects their preservation. The axial skeleton is represented mainly by coracoids, scapulae and vertebrae.

Most bird remains, except cranial remains, have been recovered complete and in anatomical connection. These features, along with the high number of elements recovered, indicate that the conditions for bone preservation in TE9c are very good.

The bird accumulation within the cavity resulted from two different dynamics. On the one hand, the high number of remains of rock-dwelling birds recovered, as well as the anatomical connections registered and the ethology of Corvus antecorax and Columba livia/oenas, suggest that these animals lived on the walls of the fissures of the cavity, they died there and afterwards they fell into the cavity, where their remains accumulated.

On the other hand, the remains of small birds, which do not typically correspond to rock-dwelling habitats, would be the result of predation by larger birds such as Falco tinnunculus or Corvus antecorax. Both species of birds use cavities and places close to them as refuges and nesting sites. In these locations they remove some of the parts of their prey that do not provide dietary nutrients (Southern, 1954; Duke et al., 1975; Glue, 1977). These skeleton 
segments fall out of the nests and into the cavity. Moreover, the activity of Falco tinnunculus could explain the low presence in this set of some of the axial elements of small birds, such as the sternum.

However, we have not identified digestion or beak marks caused by raptors on any of the bird remains. Only some of the small mammals recovered in TE9c exhibit modifications made by raptors. From taphonomic analyses, these modifications have been linked to the activities of the tawny owl (Strix aluco), although no individuals of this taxon have been recovered in the assemblage to date (Bennàsar et al., 2015).

The presence of white-tailed sea eagle (Haliaeetus albicilla) remains in level TE9c indicates that these individuals, related to wet habitats, lived in an area close to the cave. Fish and aquatic bird remains recovered in the sample have been linked to the predator activity of these birds, and the remains were subsequently introduced into the cavity by gravitational transport. Bird remains are distributed across the entire surface of level TE9c with a higher concentration in the northern area, suggesting multiple fissures or a large fissure in this area where rock-dwelling birds nested or rested (Fig. 11).

Numerous lagomorph remains (over NISP $=450$ ) were recovered from TE9c. Elements of the appendicular skeleton are the most

\section{Sima del Elefante - Atapuerca TE9c level Plan view of archaeological remains}

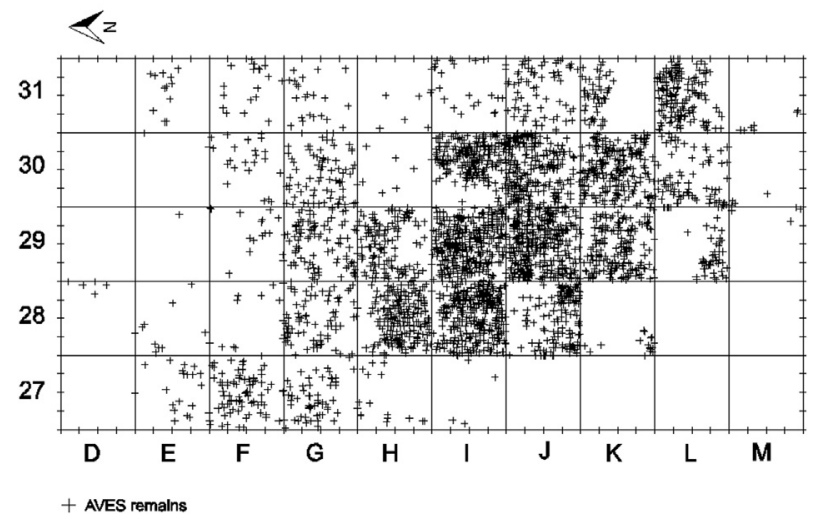

Fig. 11. Plan view of aves remains in TE9c. abundant. Most of the remains have been recovered in anatomical connection and belong to adult and immature individuals (Table 5). Some of the remains show clear evidence of tooth marks that have been related to the activity of small to medium-sized carnivores (Huguet, 2007; Huguet et al., 2013).

Table 5

Number Identified of Specimens (NISP) of lagomorph remains.

\begin{tabular}{lr}
\hline Leporidae & NISP \\
\hline Skull & 8 \\
Maxilla & 13 \\
Mandible & 23 \\
Isolated teeth & 23 \\
Scapula & 15 \\
Humerus & 41 \\
Radius & 17 \\
Ulna & 20 \\
Vertebra & 25 \\
Ribs & 5 \\
Coxae & 34 \\
Femur & 50 \\
Tibia & 49 \\
Carpal/Tarsal & 8 \\
Talus & 4 \\
Calcaneus & 37 \\
Metapodial & 45 \\
Phalange & 6 \\
Long bone & 30 \\
Total & 453 \\
\hline
\end{tabular}

The origin of the lagomorph remains in the cavity could be linked to the activities of some of their predators, like Corvidae or Falconiformes, both of which have been documented in the assemblage. However, we cannot rule out the possibility that some lagomorphs may have used this cavity as a burrow (Villafuerte, 2007).

Carnivores were the second group whose taphonomic characteristics were determined and the origin of their accumulation identified. We recovered 338 carnivore remains, belonging to four different families: Ursidae, Mustelidae, Canidae, and Felidae. The Ursidae and Mustelidae remains are scarce. Most of the carnivore specimens were recovered complete and correspond to small to medium-sized animals such as Canis mosbachensis and, mainly, Lynx sp. (Cuenca-Bescós and García, 2007; García et al., 2008) (Table 6).

Table 6

Number Identified of Specimens (NISP) of carnivore remains.

\begin{tabular}{|c|c|c|c|c|c|c|c|}
\hline NISP & $\begin{array}{l}\text { C. } \\
\text { mosbachensis }\end{array}$ & $\begin{array}{l}V . \\
\text { alopecoides }\end{array}$ & $\begin{array}{l}\text { Lynx } \\
\text { sp. }\end{array}$ & $\begin{array}{l}P . \\
\text { gombaszoegensis }\end{array}$ & $\begin{array}{l}\text { U. cf. } \\
\text { dolinensis }\end{array}$ & Mustelidae & Carnivora indet. \\
\hline Skull & - & - & 1 & - & - & - & - \\
\hline Mandible & - & - & 1 & - & - & - & - \\
\hline Maxilla & 3 & - & - & - & - & - & 1 \\
\hline Isolated teeth & 3 & - & 3 & - & 2 & - & 6 \\
\hline Scapula & - & - & 5 & 1 & - & 1 & 2 \\
\hline Humerus & - & - & 3 & - & - & - & 1 \\
\hline Radius & 1 & - & 2 & - & - & - & 2 \\
\hline Ulna & - & - & 2 & - & - & - & - \\
\hline Vertebra & 2 & - & 55 & - & - & 1 & 8 \\
\hline Ribs & 2 & - & 42 & - & - & - & 1 \\
\hline Coxae & 1 & - & 6 & - & - & - & 5 \\
\hline Femur & 1 & - & 2 & - & - & - & 1 \\
\hline Tibia & - & - & 3 & - & - & 1 & - \\
\hline Fibula & - & - & 3 & - & - & - & - \\
\hline Metapodial & 6 & 1 & 23 & - & - & 1 & 1 \\
\hline Carpal/Tarsal & 4 & - & 22 & - & - & - & 6 \\
\hline Talus & - & - & 3 & - & - & - & 1 \\
\hline
\end{tabular}


Table 6 (continued)

\begin{tabular}{|c|c|c|c|c|c|c|c|}
\hline NISP & $\begin{array}{l}\text { C. } \\
\text { mosbachensis }\end{array}$ & $\begin{array}{l}V . \\
\text { alopecoides }\end{array}$ & $\begin{array}{l}\text { Lynx } \\
\text { sp. }\end{array}$ & $\begin{array}{l}P . \\
\text { gombaszoegensis }\end{array}$ & $\begin{array}{l}\text { U. cf. } \\
\text { dolinensis }\end{array}$ & Mustelidae & Carnivora indet. \\
\hline Calcaneus & 2 & - & 4 & - & - & - & 1 \\
\hline Phalange & 8 & - & 40 & - & 1 & - & 3 \\
\hline Long bone & - & - & - & - & - & - & 12 \\
\hline Flat bone & - & - & - & - & - & - & 13 \\
\hline Indet. & - & - & - & - & - & - & 12 \\
\hline Total & 33 & 1 & 220 & 1 & 3 & 4 & 76 \\
\hline
\end{tabular}

We recovered 33 remains of Canis mosbachensis, 21 of which were in anatomical connection and belong to the same individual. Among the Felidae, we identified at least four individuals: one Panthera gombaszoegensis and three adult individuals of Lynx sp. To date, we have documented 220 remains of Lynx sp. found in anatomical connection. None of the carnivore elements exhibit carnivore damage or anthropogenic modifications. All these features (skeletons in anatomical connection, whole specimens and the absence of modifications by predators) suggest that the carnivore accumulation in the cavity is due to in situ natural death and subsequent skeletonization.

Carnivores enter cavities for different reasons. On the one hand, lynx and canids use cavities as dens in which to raise their young (Fernández and Palomares, 2000; Fernández et al., 2002; Rodríguez-Hidalgo et al., 2013). However, the absence, to date, of immature individuals in TE9c neither supports nor refutes this hypothesis. On the other hand, it is also possible that carnivores entered the cavity to search for food resources.

In TE9c, aside from small animals (birds and lagomorphs) and carnivores, ungulate remains were also recovered (NISP $=1694$ ) including Cervidae, Equidae, Bovidae, Rinocerotidae, Suidae and Proboscidea (Van der Made et al., 2003; Van der Made, 2013). These taxa remains were the third group determined according to their taphonomic characteristics and the origin of their accumulation (Table 7).
The Cervidae remains are most abundant in the subunit and correspond to two different species: Eucladoceros giulii and Dama vallonnetensis. While the remains of large animals like Proboscidea, Rinocerotidae and Equidae are scarce, the remains of medium-sized animals predominate.

We recovered the shed antlers of Dama vallonnetensis and Eucladoceros giulii in the assemblage. Cervidae shed and regrow their antlers every year. The antlers were probably shed near a fissure or entrance to the cavity and were subsequently brought in by means of gravitational transport.

Apart from antler remains, we recovered remains of all the skeletal elements of ungulates, although the limb elements were best represented (NISP $=804$ ), especially for large and mediumsized animals. In contrast to the small animal and carnivore elements, which were complete and in anatomical connexion, most of the ungulate elements were isolated and broken. Only a few distal appendicular bones (phalanges, carpals and tarsals) and some teeth were documented complete.

However, some elements in anatomical connection were recovered at the base of the level, such as part of a limb (tibia and malleolus bone) of Dama vallonnetensis and some anatomical segments of Bovidae. Forty-one bovid remains, apparently from the same individual, were recovered in anatomical connection and consisted of different skeletal segments: cranial elements (skull and mandible), axial elements (costae and vertebrae) and

Table 7

Number Identified of Specimens (NISP) grouped by ungulate remains and size weight category.

\begin{tabular}{|c|c|c|c|c|c|c|c|c|c|}
\hline NISP & Proboscidea & Rhinocerotidae & Bovidae & Equidae & Cervidae & Suidae & Large-sized & Medium-sized & Small-sized \\
\hline Antler & - & - & - & - & 32 & - & - & - & - \\
\hline Skull & - & - & 1 & - & 1 & - & 7 & 8 & 25 \\
\hline Mandible & - & - & 4 & 1 & 15 & - & 2 & 4 & - \\
\hline Maxilla & - & - & - & 1 & - & 2 & 1 & 1 & - \\
\hline Isolated teeth & 2 & - & 6 & 8 & 53 & 1 & 2 & 7 & 1 \\
\hline Scapula & - & - & 1 & - & 2 & - & 2 & 3 & 2 \\
\hline Humerus & - & - & 5 & 3 & 14 & - & 11 & 4 & 1 \\
\hline Radius & - & - & 2 & 2 & 14 & - & 1 & 6 & 1 \\
\hline Ulna & - & - & 2 & 1 & 4 & - & 1 & - & 1 \\
\hline Vertebra & - & - & - & - & - & - & 9 & 23 & 73 \\
\hline Ribs & - & - & - & - & - & - & 16 & 42 & 60 \\
\hline Coxae & - & - & 1 & - & - & - & 1 & - & 7 \\
\hline Femur & - & - & 1 & 4 & 10 & - & 5 & 3 & 7 \\
\hline Tibia & - & - & 1 & 1 & 8 & - & 7 & 7 & 3 \\
\hline Fibula & - & - & - & - & - & - & - & 1 & - \\
\hline Metapodial & - & - & 5 & 3 & 47 & - & 2 & 9 & 6 \\
\hline Carpal/Tarsal & - & 2 & 11 & 6 & 23 & - & 3 & 8 & 35 \\
\hline Talus & - & - & - & - & - & - & - & - & 1 \\
\hline Calcaneus & - & - & - & - & - & - & - & - & - \\
\hline Phalange & - & 1 & 4 & - & 18 & - & - & 1 & 6 \\
\hline Long bone & - & - & - & - & - & - & 150 & 267 & 184 \\
\hline Flat bone & - & - & - & - & - & - & 41 & 115 & 147 \\
\hline Indet. & - & - & - & - & - & - & 8 & 8 & 25 \\
\hline Total & 2 & 3 & 44 & 30 & 241 & 3 & 269 & 517 & 585 \\
\hline
\end{tabular}


appendicular elements (hands and limbs), probably after being disarticulated from the carcass.

We identified anthropogenic modifications (cut marks and breakage) on some ungulate remains (approximately 5\%), on Cervidae, Bovidae and Equidae specimens. Cut marks have been documented on all anatomical segments and the morphology of the cut marks and their distribution point to a variety of hominin activities (skinning, dismembering and defleshing) (Binford, 1981, 1984; Fisher, 1995). Impact points and flakes documented on the surface of the bones are related to anthropic breakage (Johnson, 1985; Blumenschine and Selvaggio, 1988). These modifications show that the hominin groups that occupied the Sierra de Atapuerca sites at that time performed activities such as skinning animals. This activity is one of the first steps in the butchery process of an animal carcass, and is thus related to primary and early access to the animals consumed by hominins (Bunn and Ezzo, 1993).
Consequently, we can affirm that the hominins who lived around the Sima del Elefante cave 1.2 million years ago had early and primary access to their animal prey (Fig. 12).

Some ungulate elements show carnivore-induced damage such as tooth marks (pits, punctures and scores), corrosion by gastric acid, pitting and crenulated edges. In spite of the presence of bones with carnivore modifications, their representation is too low (5\%) to determine which carnivore taxa acted on this assemblage. However, among the set of bones broken by carnivore action, some can be attributed to a large to medium-sized carnivore, possibly a canid or hyena.

This damage caused by carnivores has been documented on the shaft of the long bones; most of the items identified with this type of damage were the epiphyses and near epiphyses of the long bones and ribs, and elements which are highly spongy, such as vertebral bodies, phalanges and tarsals/carpals. This type of consumption by

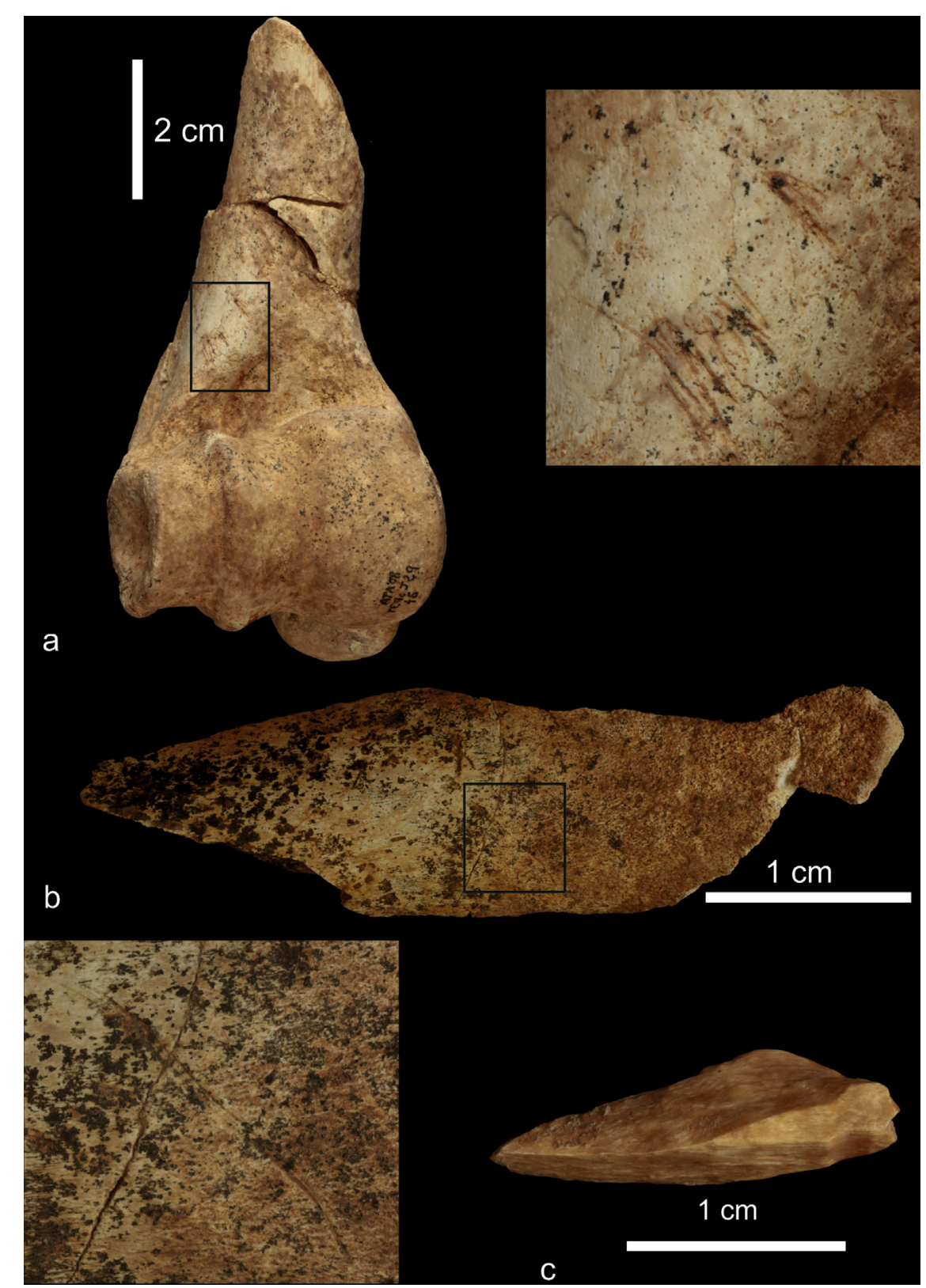

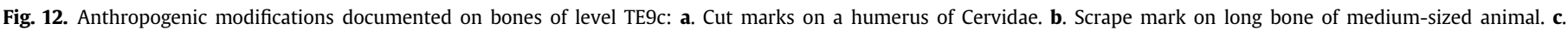
Conchoidal flake of a long bone from a medium-sized animal. 
the Sierra de Atapuerca carnivores suggest their secondary access to the assemblage generated by hominins (Huguet et al., 2013; Saladié et al., 2014).

Anthropogenic modifications on ungulate remains indicate that hominins played a role in the origin or process of bone accumulations in the cavity. The absence of anatomical connections among the skeletons, the high degree of fragmentation of the bones and the cut marks identified suggest that the ungulate remains recovered in TE9c may have been abandoned by hominins after the processing and consumption of these animals. The bovid elements recovered in anatomical connection may be the result of a butchery process left unfinished by hominins for some unknown reason.

The anthropogenic modifications identified on ungulate remains point to the origin of accumulation of the third group of faunal remains recovered in TE9c is related to the hominin occupation of the site. An important question about the ungulate accumulation in the cavity is whether this set is in primary or secondary position: whether hominins occupied the site (TE9c) of Sima del Elefante itself or whether they occupied a place nearby the site and these remains entered the cavity by gravitational or hydric transport in dense clayey sediment.

\subsection{Palaeobotanical record}

In this level, the palaeobotanical data come from the palynological and charcoal records. The concentration of pollen and nonpollen palynomorphs (NPP) is very low. Level TE9c yielded evidence of the presence of conifers (Pinus sp. and Cupressaceae), and hazel (Corylus) as tree species and wild grasses (Poaceae), and Asteraceae as herbaceous taxa.

The identified NPP include algal taxa like Gloeotrichia, other fungal palynomorphs related to the Sordariaceae family and some chitinous remains. Cluster analysis applied to the palynological results shows that the samples from TE9c form an isolated group with unique characteristics compared to the rest of the sequence (Fig. 13).

Charcoal is scarce and poorly preserved. However, some taxa were identified using an optical microscope. The analyses of 55 charcoal fragments from TE9c have distinguished Acer sp., cf.
Prunus, deciduous Quercus sp., undetermined angiosperms and undetermined conifer.

\subsection{Palaeoecological settings}

The paleontological and palaeobotanical data from level TE9c make it possible to reconstruct the palaeoecological conditions during which the level was formed around 1.2 million years ago. According to palaeobotanical data, the presence of evergreen Quercus, Pinus spp., and Cupressaceae is consistent with the existence of a typical Mediterranean climatic context, perhaps a little wetter than expected, as indicated by the presence of mesic and riparian trees such as Corylus in the palynological results and Acer sp. and deciduous Quercus sp. in the anthracological record. It should be noted that the Mediterranean conditions of level TE9c which imply a warm and seasonally dry climate are corroborated by the identification of Olea-Phillyrea in an earlier analysis of unit TE9 (Rodríguez et al., 2011).

The presence of high values of microscopic charcoal in palynological slides is typically interpreted in this timeframe as an increase in the natural occurrence of fire, and may suggest a dry season or periods of drought. In the TE9c samples, the values of microcharcoal are low. In fact, only after in TE9b a slight increase occurs, perhaps related to an increase in seasonal dryness typical of the Mediterranean climate (Rosas et al., 2004, 2006; Rodríguez et al., 2011; Expósito et al. 2015).

Palaeontological data of TE9c level of Sima del Elefante indicate warm conditions: climatic reconstruction, using the mutual climatic range method on the herpetofauna assemblage from level TE9c, suggests a mean annual temperature of $12.5 \pm 1.3{ }^{\circ} \mathrm{C}$ and mean annual precipitation equal to $897 \pm 111 \mathrm{~mm}$ (Blain et al., 2010). The small vertebrates as T. cf. marmoratus, A. obstetricans, B. bufo, Rana sp., A. gibberondon, B. fissidens, Sorex spp., G. cf. kormosi, Castor sp., A. jacobea, Heliaeetus albicilla and salmonids are characteristic inhabitants of humid habitats with high rainfall and permanent rivers or ponds, as well as wet meadows (Sanchez Marco, 2002, 2004; Rofes and Cuenca-Bescós, 2006; Rofes and Cuenca, 2009; Blain et al., 2010; Rofes and Cuenca-Bescós, 2013; Rofes et al., 2014).

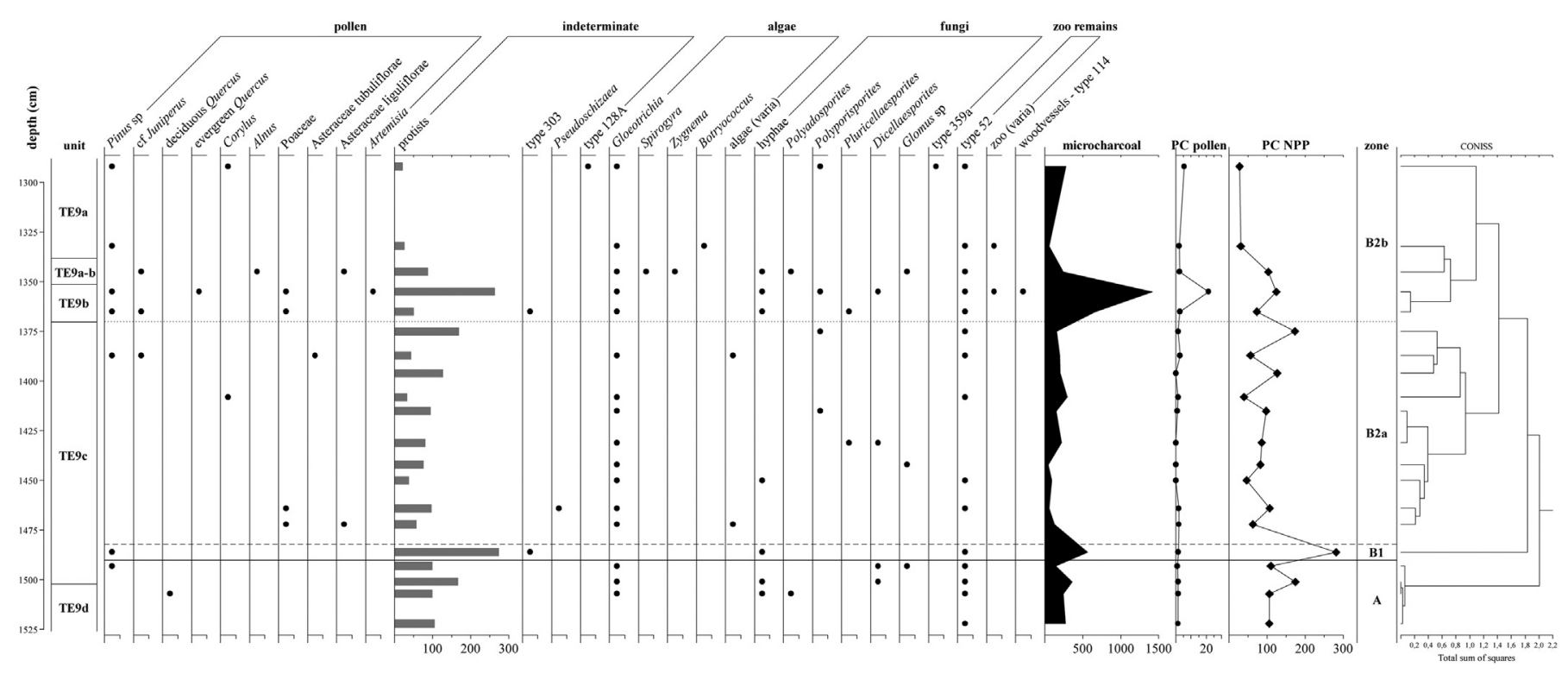

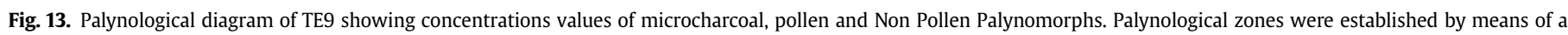
clusters analysis based on square root transformation (Edwards and Cavalli-Sforza's chord distance) using CONISS (Grimm, 1987). 
The large mammal assemblage of TE9c also suggests patchy landscape conditions. The presence of typical woodland and woodland-edge fauna such as cervids (Eucladoceros giulli, and Dama vallonnetensis) in association with open-land taxa such as horses (Equus altidens), rhinos (Stephanorhinus sp.) and bovids (Bison cf. menneri) suggests an alternating landscape formed by grasslands and forested areas. In the same way, the amphibian and reptile taxa (Blain et al., 2010) and a bird of prey identified as a predator of the micromammals in TE9c (S. aluco) (Bennàsar et al., 2015) suggest an environment with open habitats, with wet areas in the surrounding zone and a predominance of wet meadows and open woodlands. Nevertheless, we have also identified small vertebrate species, such as $P$. cultripes and, to a lesser extent, C. kornfeldi, Allophaiomys spp., B. calamita, Pelodytes punctatus and Testudo hermanni (Huguet, 2007; Blain et al., 2010; Blasco et al., 2011; Rofes and Cuenca-Bescós, 2011) associated with open environments, scant vegetation cover and loose rocky soils.

Non Pollen Palynomorphs (NPP) results indicate the existence of humidity inside or around the cave. This local moisture may have stimulated the growth of some microalgae taxa like Gloeotrichia and Botryococcus. These kinds of microorganisms are related to oligotrophic environments and contribute to nitrogen fixation, helping in the process of soil enrichment (Expósito et al., 2015).

\section{Discussion}

Level TE9c of Sima del Elefante is one of most important archaeological sites in the study of European human evolution. This assemblage and the results obtained have both contributed to answering questions related to human evolution research and raised new questions as well.

\subsection{When did humans arrive?}

One of the main contributions of the TE9c assemblage is its age. Until 2007, the oldest western European site with human remains associated with stone tools and bones with anthropogenic modifications was level 6 of the Gran Dolina (TD6) site, with an age of $\geq 0.8 \mathrm{Ma}$ (Carbonell et al., 1995). Although it is true that there were sites with archaeological evidence that predates TD6 in western Europe, such as level 4 of Gran Dolina (Carbonell and Rodríguez, 1994) Le Vallonnet (Lumley de et al., 1988), Fuente-Nueva 3 and Barranco León (Oms et al., 2000), none of these sites had yielded human remains up to 2007.

Cosmogenic nuclide dating, biostratigraphic markers and palaeomagnetism together with human remains, indicate without a doubt the fact that there was a human presence in Europe at least 1.2 million years ago (Carbonell et al., 2008). The number of sites with evidence of Early Pleistocene humans in Europe is currently growing, such as La Boella (La Canonja) (Vallverdú et al., 2014) and Vallparadís (Terrassa) (Martínez et al., 2010) in Spain. Sites with chronologies more than a million years have even been discovered, such as Pirro Nord and Monte Poggiolo (Arzarello and Peretto, 2010) in Italy and Bois de Riquet (Crochet et al., 2009; Bourguignon et al. 2015) and Pont de Lavaud (Despriée et al., 2010) in France.

The confirmation of the human presence in Europe at least to 1.2 Ma obtained from the TE9c findings implied a strong support to the paradigm that advocates for an early human occupation in western Europe (Carbonell et al., 1995, 1999). Since that time, the chronological debate has focused on determining how far back the human presence in Europe might go.

\subsection{Who were they?}

The human remains recovered in TE9c are another important contribution of this assemblage to research on human evolution. Although only a few human remains have been detected so far, a mandible and a phalange to date, make it possible to pose some hypotheses about the hominin groups that inhabited Europe during the Early Pleistocene. Initially, these human remains were provisionally assigned to Homo antecessor. This assignation by Bermúdez de Castro et al. (2010) was linked to an interpretation about the possible origin of these hominins. These authors proposed that the hominins that inhabited the area around Sima del Elefante 1.2 Ma ago may be related to the first demographic expansion out of Africa, currently represented by Dmanisi hominins. Moreover, the Sima del Elefante findings may indicate that a speciation event occurred in this extreme part of Eurasia during the Early Pleistocene, initiating the hominin lineage represented by the TE9c and TD6 specimens. However, Bermúdez de Castro et al. (2011) conducted a detailed comparative morphological study and, in the absence of any additional evidence, prefer not to include specimen ATE9-1 in any named taxon, but rather refer to it as Homo sp. The study of the mandible (ATE9-1) revealed the presence of morphological features distinct from those typical of African early Homo and the Dmanisi hominins. This new data on the morphological features of ATE9-1 led Bermúdez de Castro et al. (2011) to question whether their previous interpretation linking the TE9 remains with Dmanisi hominins is feasible. These authors propose that 'the temporal distance between the Dmanisi and Sima del Elefante sites may be around $400 \mathrm{ka}$, time enough for the former population to evolve its own distinguishing features". Moreover, the difficulty of the dispersal of the first African emigrants (geographic barriers and climatic factors) until reaching western Europe could have favoured genetic drift, long isolation periods, and localized adaptation to new climatic and seasonal conditions. Given these conditions, one or more speciation events could have occurred in this extreme part of Eurasia during the Early Pleistocene, originating in the hominin lineages represented by the Sima del Elefante-TE9, and, possibly, the Gran Dolina-TD6 hominins (Bermúdez de Castro et al., 2011).

Thus, the oldest human remains recovered in south-western Europe have raised more questions than they have answered. But, it is important to remember that as yet the human record is very sparse. The Barranco León site has yielded a tooth belonging to an immature individual; however, the age of the item makes it impossible to assign it to any named taxon (Toro-Moyano et al., 2013).

Establishing whether the human remains recovered in level 9c (TE9c) of Sima del Elefante, in Barranco León and level 6 (TD6) of Gran Dolina correspond to the same or different lineages would be key to determining if human settlements in Europe, at least during the Early Pleistocene, were continuous or, as suggested by some researchers, they were intermittent (Gamble, 1995; Roebroeks, 2001, 2006; Dennell, 2003). So far, it has not been possible to establish the relationship between the human remains recovered in both sites. However, the European Early Pleistocene hominin record will continue growing and its comparison with the remains from TE9c will be crucial.

\subsection{Where did they live?}

One of the issues raised during the study of the archaeological remains recovered from level TE9c was determining whether ungulate remains, which show anthropogenic modifications, are in a primary or secondary position, in other words, whether hominins occupied the site (TE9c) of Sima del Elefante itself or settled at a place nearby the site. The presence of elements in anatomical 
connection, mainly birds and lagomorph remains, indicates that the bone preservation conditions in the cave are very good. Therefore, we suggest that the absence of whole skeletons or more complete anatomical segments of the numerous ungulate remains inside the cavity are not due to a preservation problem, but rather to the fact that the bodies of these animals were never complete in that location. On the other hand, the low number of stone tools, the fragmented chaîne opératoire and the absence of lithic refitting suggest that hominins did not carry out tool flaking activities inside the cave.

Finally, the mud deposits in fine beds point to environmental conditions in which water was poorly drained and formed the palustrine ponds and mud plains described in the depositional systems of the distal zones of alluvial fan models (Colombo, 1989; Collinson, 1996). Consequently, level TE9c contains a temporary water pool. These environmental conditions would be fairly favourable to a human occupation inside the cave.

All of these features suggest that hominins did not occupy the cave, and consequently, the archaeological remains recovered are in secondary position. However, the good state of preservation of the ungulate remains and the occurrence of a core fragment and a flake that seem to belong to the same nodule of Cretaceous chert suggest that hominins settled somewhere near the TE9c site (Carbonell et al., 2008; Huguet et al., 2013; Ollé et al., 2013; de LomberaHermida et al., 2015). The hominins settled at this nearby location and some of the evidence of their activities (mainly stone tool production and animal butchering) was brought into the cave by means of gravitational transport or mudflows.

Where hominins choose to settle is a key decision for the survival of the group. According to Jochim (1976), the success of the place chosen is related to the advantages of the region occupied and its surrounding area. The landscape, climatic conditions, type of vegetation, the presence of resources, stone or food, the existence of water sources, places of refuge and the degree of competition with other predators are some of the variables influencing the stability of human groups in a location.

The paleoecological data from TE9c illustrates the scenario in which the early hominins settled. The climatic conditions suggest a typical Mediterranean context that was warmer and rainier than in Burgos today. These hominins settled in an area rich in all of the necessary resources including water, animal-plant and lithic resources, as well as sheltered areas.

The optimal palaeoecological conditions of the landscape and sufficiently developed subsistence strategies allowed the TE9c hominins to successfully exploit these resources. This would have ensured the survival and reproduction of the groups of hominins 1.2 Ma.

\subsection{What were their subsistence strategies?}

The archaeological remains recovered in level TE9c have provided data on some aspects of the subsistence strategies of the human groups that inhabited Europe around 1.2 Ma. Competition between carnivores and hominins is an often debated issue in relation to the development of subsistence strategies among early human groups. Some researchers (Martínez Navarro and Palmqvist, 1995; Arribas and Palmqvist, 1999; Martínez Navarro and Palmqvist, 1999) have proposed that hominins would not have been able to have primary and early access (hunting or confrontational scavenging) to animal resources, but rather they would have fed on carrion left by large carnivores, which would have made them totally dependent on carnivores for their survival.

However, the identification of the primary and early access to prey by the TE9c hominins implies that it was obtained by means of hunting or confrontational scavenging practices. Doubt has often been cast on these hominins' ability to hunt based on the extent of their technological and social organization (Gamble, 2001; Roebroeks, 2006). However, some authors have proposed that hunting is sometimes less dangerous than confrontational scavenging (Domínguez-Rodrigo and Barba, 2006). It is possible that the hominins used different strategies, both hunting and scavenging (active and passive), to obtain animal resources. In any case, primary and early access to prey is only a successfully strategy if the group members enjoy social cooperation and some degree of complexity in their relationships.

The data from TE9c show that hominins had primary access to prey, regardless of the size of the animal, while carnivores had both primary and secondary access to the prey that they consumed. The hominins may have occasionally had secondary access to carcasses abandoned by carnivores, although this scenario has not been identified in TE9c.

The existence of carnivore scavenging of the remains left by hominins is important to determine the degree of competition between the guild of carnivores and hominins in Europe during the Early Pleistocene. The data from TE9c indicate that the competition between carnivores and hominins may have been high, although both groups of predators would have been at the top of the trophic network and the hominins did not depend on the remains left by the carnivores for food (Huguet et al., 2013; Saladie et al., 2014). The lithic assemblage recovered from TE9c is characterized by an immediacy of raw material resources and technical investment. The lithic production is aimed at obtaining flakes with sharp cutting edges (related to butchery activities) and not at producing blanks for subsequent tool shaping. The use of nearby lithic resources shows that one of the keys to success of these human groups consisted of settling in areas with high resource availability. All of these features (the control of resources in the territory, primary access to prey, the independence of carcases left by carnivores and social cooperation) would indicate that the hominins that inhabited Europe during the Early Pleistocene were capable to employ complex subsistence strategies based on the opportunistic and indiscriminate exploitation of resources (Saladié et al., 2011; Huguet et al., 2013).

\section{Conclusions}

The study of the findings from level TE9c has provided new data that has allowed us to better understand the early human occupation of Europe. These data have shown that the first humans inhabited western Europe at least 1.2 Ma. The scarcity of human remains of Homo sp. in this assemblage has not made it possible, so far, to assign them. However, the data collected from the site allow us to affirm that these hominins settled in a landscape such as the Sierra de Atapuerca with a Mediterranean climate and abundant biotic and abiotic resources. These hominins were most likely in a situation of high competition with other predators that lived in the landscape, but their primary and early access to animal carcasses suggest that their subsistence strategies were successful to ensure their survival as a group. These hominins did not use the Sima del Elefante cave as a place of occupation, thus the archaeological remains recovered in this assemblage are in secondary position, although paleontological remains including birds, leporids and carnivores seem to be in primary position. Some of these findings have given rise to a paradigm shift concerning, for example, the age of the first human settlements in western Europe. In other aspects, such as the taxonomic identification of the first hominins that occupied western Europe or the understanding of their social and technological capabilities, no paradigm shift has occurred, but key data have been presented that give rise to new questions and enrich the debate about human evolution. 


\section{Acknowledgements}

We are grateful to the Atapuerca research team, participants in the fieldwork. This research project was supported by MINECO projects (CGL2012-38434-C03-03, CGL2012-38434-C03-02, CGL2012-38434-C03-01, HAR 2012-032548/HIST, HAR2013-41197P) and AGAUR project (2014SGR-899, 2014-SGR 901). The field excavation work was supported by Junta de Castilla y León and Fundación Atapuerca. We are grateful to Ángel Blanco for his review about species of fishes recovered in TE9c. A.L.H. was beneficiary of a predoctoral grant from Fundación Atapuerca. M.S. received a FI grant (FI-DGR 2013) from Generalitat de Catalunya. M.T.-B. has been a scholarship holder of "Cátedra Atapuerca". J.R. has a postdoc Marie Curie Fellowship (MCA-IEF Project $n^{\circ} 629604$ ) of the European Commission. M.M research has been supported by a predoctoral grant (BOCYL-D-30122013-33) and economic support by the Atapuerca Foundation. C. Núnez-Lahuerta is the recipient of a Ph.D. fellowship from the Gobierno de Aragon (DGA). TWe also acknowledge the comments and suggestions made by Dr. Philippe Fernandez and one anonymous reviewer.

\section{References}

Arnold, L., Demuro, M., 2015. Insights into TT-OSL signal stability from single-grain analyses of known-age deposits at Atapuerca, Spain. Quaternary Geochronology 30 Part B, 472-478.

Arribas, A., Palmqvist, P., 1999. On the ecological connection between sabre-tooths and hominids: faunal dispersal events in the lower Pleistocene and a review of the evidence for the first human arrival in Europe. Journal of Archaeological Science 26, 571-585.

Arzarello, M., Peretto, C., 2010. Out of Africa: the first evidence of Italian peninsula occupation. Quaternary International 223-224, 65-70.

Bennàsar, M. Cáceres, I., Cuenca-Bescós, G, 2015. Paleoecological and microenvironmental aspects of the first european hominids inferred from the taphonomy of small mammals (Sima del Elefante, Sierra de Atapuerca, Spain). Palevol (in press).

Bermúdez de Castro, J.M., Martinón-Torres, M., Gómez-Robles, A., Prado-Simón, L. Carbonell, E. 2010. New human evidence of the Early Pleistocene settlement of Europe, from Sima del Elefante site (Sierra de Atapuerca, Burgos, Spain). Quaternary International 223-224, 431-433.

Bermúdez de Castro, J.M., Martinón-Torres, M., Gómez-Robles, A., Prado-Simón, I Martín-Francés, L., Lapresa, M., Olejniczak, A., Carbonell, E., 2011. Early Pleistocene human mandible from Sima del Elefante (TE) cave site in Sierra de Atapuerca (Spain): a comparative morphological study. Journal of Human Evolution 61 (1), 12-25.

Binford, L., 1981. Bones: Ancient Men and Modern Myths. Academic Press, New York.

Binford, L., 1984. Butchery, sharing, and the archaeological record. Journal of Anthropological Archaeology 3, 235-237.

Blain, H.-A., Bailon, S., Cuenca-Bescós, G., Bennàsar, M., Rofes, J., López-García, J.M., Huguet, R., Arsuaga, J.L., Bermúdez de Castro, J.M., Carbonell, E., 2010. Climate and environment of the earliest West European hominins inferred from amphibian and squamate reptile assemblages: Sima del Elefante Lower Red Unit, Atapuerca, Spain. Quaternary Science Reviews 29 (23-24), 3034-3044.

Blasco, R., Blain, H.-A., Rosell, J., Díez, J.C., Huguet, R., Rodríguez, J., Arsuaga, J.L., Ber múdez de Castro, J.M., Carbonell, E., 2011. Earliest evidence for human consumption of tortoises in the European Early Pleistocene from Sima del Elefante Sierra de Atapuerca, Spain. Journal of Human Evolution 61 (4), 503-509.

Blumenschine, R.J., Selvaggio, M., 1988. Percussion marks on bone surfaces as a new diagnostic of hominid behavior. Nature 333, 763-765.

Bourdier, F., 1961. Le Bassin du Rhône au Quaternaire. Géologie et préhistoire. In: Texte, Tome I. Centre National de la Recherche Scientifique, Paris, p. 364.

Bourguignon, L., Crochet, J.-Y., Capdevila, R., Ivorra, J., Antoine, P.-O., Agustí, J Barsky, D., Blain, H.-A., Boulbes, N., Bruxelles, L., Claude, J., Cochard, D., Filoux, A Firmat, C., Lozano-Fernández, I., Magniez, P., Pelletier, M., Rios-Garaizar, J., Testu, A., Valensi, P., De Weyer, L., 2015. Bois-de-Riquet (Lézignan-la-Cèbe, Hérault): a late Early Pleistocene archeological occurrence in southern France. Quaternary International. http://dx.doi.org/10.1016/j.quaint.2015.06.037.

Bunn, H.,T., Ezzo, A.J., 1993. Hunting and scavenging by Plio-pleistocene hominids: nutritional constraints, archaeological patterns, and behavioural implications. Journal of Archaeological Science 20, 365-398.

Campy, M., 1986. Les cortex d'altération des éléments calcaires dans les remplissages de porche. Implications dynamiques et chronologiques. Bulletin de l'Association française pour létude du Quaternaire 271-280.

Carbonell, E., Rodríguez, X.P., 1994. Early Middle Plesitocene deposits and artefacts in the Gran Dolina site (TD4) of the Sierra de Atapuerca (Burgos, Spain). Journal Human of Evolution 25, 291-311.

Carbonell, E., Bermúdez de Castro, J.M., Arsuaga, J.L., Díez, J.C., Rosas, A., CuencaBescòs, G., Sala, R., Mosquera, M., Rodríquez, X.P., 1995. Lower Pleistocene hominids and artifacts from Atapuerca-TD6 (Spain). Science 269, 729-892.
Carbonell, E., García -Anton, D., Mallol, C., Mosquera Martinez, M., Olle, A., Rodriguez, X.P., Sahnouni, M., Sala, R., Verges, J.M., 1999. The TD6 level lithic industry from Gran Dolina, Atapuerca (Burgos,Spain): production and use. Journal of Human Evolution 37 (3/4), 653-694.

Carbonell, E., Bermúdez de Castro, J.M., Parés, J.M., Pérez-González, A., CuencaBescós, G., Ollé, A., Mosquera, M., Huguet, R., Van der Made, J., Rosas, A., Sala, R., Vallverdú, J., García, N., Granger, D.J., Martinón-Torres, M., Rodríguez, X.P., Stock, G.M., Vergés, J.M., Allué, E., Burjachs, F., Cáceres, I., Canals, A., Benito, A., Díez, C., Lozano, M., Mateos, A., Navazo, M., Rodríguez, J., Rosell, J., Arsuaga, J.L., 2008. The first hominin of Europe. Nature 452, 465-469.

Collinson, J.D., 1996. Alluvial Sediments. Sedimentary Environments: Processes, Facies and Stratigraphy. H. Reading. Blackwell Science, Oxford, pp. 37-82.

Colombero, S., Pavia, M., Rook, L., 2012. Pannonictis nestii (Galictinae, Mustelidae), a new element in the vertebrate association of the human site of Pirro Nord (Italy, Early Pleistocene). Geodiversitas 34 (3), 665-681. http://dx.doi.org/10.5252/ g2012n3a11.

Colombo, F., 1989. Abanicos aluviales. In: Arche, A. (Ed.), Sedimentología. Consejo Superior de Investigaciones Científicas (CSIC), Madrid, pp. 143-218.

Crochet, J.Y., Welcomme, J.L., Ivorra, J., Ruffet, G., Boulbes, N., Capdevila, R., Claude, J., Firmat, C., Métais, G., Michaux, J., Pickford, M., 2009. Une nouvelle faune de vertébrés continentaux, associée à des artefacts dans le Pléistocène inférieur de l'Hérault (Sud de la France), vers 1,57 Ma. Comptes Rendus Palevol 8 (8), 725-736.

Cuenca-Bescós, G., García, N., 2007. Biostratigraphic succession of the Early and Middle Pleistocene mammal faunals of the Atapuerca cave sites (Burgos, Spain). Courier Forschunginstitut Senckenberg 259, 99-110.

Cuenca-Bescós, G., Rofes, J., López-García, J.M., Blain, H.-A., De Marfá, R.J., GalindoPellicena, M.A., Bennásar-Serra, M.L., Melero-Rubio, M., Arsuaga, J.L., Bermúdez de Castro, J.M., Carbonell, E., 2010. Biochronology of Spanish Quaternary small vertebrate faunas. Quaternary International 212 (2), 109-119.

Cuenca-Bescós, G., Rofes, J., López-García, J.M., Blain, H.A., Rabal-Garcés, R., Sauqué, V., Arsuaga, J.L., Bermúdez de Castro, J.M., Carbonell, E., 2013. The small mammals of Sima del Elefante (Atapuerca, Spain) and the first entrance of Homo in Western Europe. Quaternary International 295, 28-35.

Cuenca-Bescós, G., Blain, H.-A., Rofes, J., Lozano-Fernández, I., López-García, J.M., Duval, M., Galán, J., Núñez-Lahuerta, C., 2015. Comparing two different Early Pleistocene microfaunal sequences from the caves of Atapuerca, Sima del Elefante and Gran Dolina (Spain): biochronological implications and significance of the Jaramillo subchron. Quaternary International. http://dx.doi.org/10.1016/ j.quaint.2014.12.059.

de Lombera-Hermida, A., Bargalló, A., Terradillos-Bernal, M., Huguet, R. Vallverdú, J., García-Antón, M.-D., Mosquera, M., Ollé, A., Sala, R., Carbonell, E., Rodríguez-Álvarez, X.P., 2015. The lithic industry of Sima del Elefante (Atapuerca, Burgos, Spain) in the context of Early and Middle Pleistocene technology in Europe. Journal of Human Evolution 82, 95-106.

Dennell, R., 2003. Dispersal and colonisation, long, short chronologies: how continuous is the Early Plesitocene record for hominids aoutside East Africa? Journal of Human Evolution 45, 421-440.

Despriée, J., Voinchet, P., Tissoux, H., Moncel, M.H., Arzarello, M., Robin, S., Bahain, J.J., Falguères, C., Courcimault, G., Dépont, J., Gageonnet, R., Marquer, L., Messager, E., Abdessadok, S., Puaud, S., 2010. Lower and middle Pleistocene human settlements in the Middle Loire River Basin, Centre Region, France. Quaternary International 223-224, 345-359.

Domínguez-Rodrigo, M., Barba, R., 2006. New estimates of tooth mark and percussion mark frequencies at the FLK Zinj site: the carnivore-hominid-carnivore hypothesis failed. Journal of Human Evolution 50, 170-194.

Duke, G.E., Jeers, A.A., Loft, G., Evanson, O.A., 1975. Gastric digestion in some systems. Comparative Biochemistry and Physiology 50, 649-656.

Expósito, I., Burjachs, F., Allué, E., 2015. Filling in the gaps: the contribution of nonpollen palynomorphs to knowledge about the local environment of the Sierra de Atapuerca caves during the Pleistocene. Quaternary International. http:// dx doi org/101016/j-quaint2015.09.016.

Féblot-Augustins, J., 1999. Raw material transport patterns and settlement systems in the European Lower and Middle Palaeolithic: continuity, change and variability. In: Roebroeks, W., Gamble, C. (Eds.), The Middle Palaeolithic Occupation of Europe University of Leiden and European Science Foundation, pp. 193-214.

Fernández, N., Palomares, F., 2000. The selection of breeding dens by the endangered Iberian lynx (Lynx pardinus): implications for its conservation. Biological Conservation 94, 51-61.

Fernández, N., Palomares, F., Delibes, M., 2002. The use of breeding dens and kitten development in the Iberian lynx (Lynx pardinus). Journal of Zoological 258 (1), $1-5$

Fisher, J.W., 1995. Bone surface modifications in zooarchaeology. Journal of Archaeological Method and Theory 2 (1), 7-68.

Galán, J., Cuenca-Bescós, G., López-García, J.M., 2015. The fossil bat assemblage of Sima del Elefante Lower Red Unit (Atapuerca, Spain): first results and contribution to the palaeoenvironmental approach to the site. Comptes Rendus Paleovol. http://dx.doi.org/10.1016/j.crpv.2015.06.002, (in press).

Gamble, C., 1995. The earliest occupation of Europe: the environmental background. In: Roebroeks, W., van Kolfschoten, T. (Eds.), The Earliest Occupation of Europe. University of Leiden, Leiden, pp. 279-295.

Gamble, C., 2001. Las sociedades paleolíticas de Europa. Ariel, Barcelona.

García, N., Howel, F.C., 2008. New discovery of a large mustelid (Carnivora:Mammalia) from the early Pleistocene locality of Sima del Elefante (Sierra de 
Atapuerca, Spain). Palaeontographica Abteilung A: Palaozoologie, Stratigraphie $284(1-3), 1-16$.

García, N., Arsuaga, J.L., Bermúdez de Castro, J.M., Carbonell, E., Rosas, A., Huguet, R., 2008. The Epivillafranchian carnivore Pannonictis (Mammalia, Mustelidae) from Sima del Elefante (Sierra de Atapuerca, Spain) and a revision of the Eurasian occurrences from a taxonomic perspective. Quaternary International 179 (1), 42-52.

Glue, D.E., 1977. Feeding ecology of the short eared owl in Britain and Ireland. Bird Study 24, 70-78.

Granger, D.E., Fabel, D., Palmer, A.N., 2001. Pliocene-Pleistocene incision of the Green River, Kentucky, determined from radioactive decay of cosmogenic ${ }^{26} \mathrm{Al}$ and ${ }^{10} \mathrm{Be}$ in Mammoth Cave sediments. Geological Society of America Bulletin $113,825-836$.

Grimm, E.C., 1987. CONISS: a FORTRAN 77 program for stratigraphically constrained cluster analysis by the method of incremental sum of squares. Computers \& Geosciences 13, 13-35.

Huguet, R., 2007. Primeras ocupaciones humanas en la Península Ibérica: Paleoeconomía en la Sierra de Atapuerca (Burgos) y la Cuenca de Guadix-Baza (Granada) durante el Peistoceno Inferior. Universitat Rovira i Virgili, Tarragona.

Huguet, R., Saladié, P., Cáceres, I., Díez, C., Rosell, J., Bennàsar, M., Blasco, R., EstebanNadal, M., Gabucio, J., Rodríguez-Hidalgo, A., Carbonell, E., 2013. Successful subsistence strategies of the first humans in south-western Europe. Quaternary International 295, 168-182.

Jochim, M.A., 1976. Hunter-Gatherer Subsistence and Settlement. A Prespective Model. Academic Press, New York, London.

Johnson, E., 1985. Current developments in bone technology. Advances in Archaeological Method and Theory 8, 157-235.

Kahlke, R.D., 2007. Late Early Pleistocene European large mammals and the concept of an Epivillafranchian biochron Late Neogene and Quaternary biodiversity and evolution: Regional developments and interregional correlations. In: Proceedings of the 18th International Senckenberg Conference (VI International Palaeontological Colloquium in Weimar)., Courier Forschungsinstitut Senckenberg.

Laplana, C., Cuenca-Bescós, G., 2000. Una nueva especie de Microtus (allophaiomys) (Arvilolidae, Rodentia, Mammalia) en el Pleistoceno inferior de la Sierra de Atapuerca (Burgos, España). Revista española de paleontología 15 (1), 78-87.

López-García, J.M., Blain, H.A., de Marfà, R., García, A., Martinell, J., Bennasar, M.L., Cuenca-Bescós, G., 2011. Small-mammals from the Middle Pleistocene layers of the Sima del Elefante (Sierra de Atapuerca, Burgos, northwestern Spain). Geologica Acta 9 (1), 29-43.

Lorenzo, C., Pablos, A., Carretero, J.M., Huguet, R., Valverdú, J., Martinón-Torres, M., Arsuaga, J.L., Carbonell, E., Bermúdez de Castro, J.M., 2015. Early Pleistocene human hand phalanx from the Sima del Elefante (TE) cave site in Sierra de Atapuerca (Spain). Journal of Human Evolution 78, 114-121.

Lowe, D., Waltham, T., 1995. A Dictionary of Karst and Caves. BCRA, Somerset.

Lumley de, H., Fournier, A., Krzepkowska, J., Echassoux, A., 1988. L'industrie du Pléistocène Inférieur de la grotte du Vallonnet Roquebrune-Cap-Martin, AlpesMaritimes. L'Anthropologie 92 (2), 501-614.

Martínez, K., Garcia, J., Carbonell, E., Agustí, J., Bahain, J.J., Blain, H.A., Burjachs, F., Cáceres, I., Duval, M., Falguères, C., Gómez, M., Huguet, R., 2010. A new Lower Pleistocene archeological site in Europe (Vallparadís, Barcelona, Spain). Proceedings of the National Academy of Sciences of United States of America (PNAS) 13, 5762-5767.

Martínez-Navarro, B., Palmqvist, P., 1995. Presence of the African Machairodont Megantereon whitei (Broom, 1937) (Felidae, Carnivora, Mammalia) in the Lower Pleistocene site of Venta Micena (Orce, Granada, Spain) with some considerations on the origin, evolution and dispersal of the genus. Journal of Archaeological Science 22, 569-582.

Martínez-Navarro, B., Palmqvist, P., 1999. Venta Micena (Orce, Granada, Spain): Human Activity in a Hyena Den during the Lower Pleistocene. In: The Role of Early Human in the Accumulation of European Lower and Middle Palaeolithic Bone Assemblage, vol. 42. Monographien des Römisch-Germanishen Central museums, Mania.

Martinón-Torres, M., Martín-Francés, L., Gracia, A., Olejniczak, A., Prado-Simón, L., Gómez-Robles, A., Lapresa, M., Carbonell, E., Arsuaga, J.L., Bermúdez de Castro, J.M., 2011. Early Pleistocene human mandible from Sima del Elefante (TE) cave site in Sierra de Atapuerca (Spain): a palaeopathological study. Journal of Human Evolution 61 (1), 1-11.

Ollé, A., Mosquera, M., Rodríguez, X.P., de Lombera-Hermida, A., García-Antón, M.D., García-Medrano, P., Peña, L., Menéndez, L., Navazo, M., Terradillos, M., Bargalló, A., Márquez, B., Sala, R., Carbonell, E., 2013. The Early and Middle Pleistocene technological record from Sierra de Atapuerca (Burgos, Spain). Quaternary International 295, 138-167.

Oms, O., Parés, J.M., Martínez-Navarro, B., Agustí, J., Toro, I., Martínez-Fernández, G., Turq, A., 2000. Early human occupation of western Europe: Paleomagnetic dates for two paleolithic sites in Spain. Proceedings of the National Academy of Sciences of United States of America (PNAS) 97 (19), 10666-10670.

Ortega, A.I., Benito-Calvo, A., Pérez-González, A., Carbonell, E., Bermúdez de Castro, J.M., Arsuaga, J.L., 2014. In: F.G., M.G. (Eds.), Atapuerca Karst and its Palaeoanthropological Sites Landscapes and Landforms of Spain, World Geomorphological Landscapes. Springer Science + Business Media, Dordrecht.
Parés, J.M., Pérez González, A., Rosas, A., Benito, A., Bermúdez de Castro, J.M. Carbonell, E., Huguet, R., 2006. Matuyama-age lithic tools from the Sima del Elefante site, Atapuerca (northern Spain). Journal of Human Evolution 50, 163-169.

Rodríguez, J., Burjachs, F., Cuenca-Bescós, G., García, N., Van der Made, J., Pérez González, A., Blain, H.A., Expósito, I., López-García, J.M., García Antón, M., Allué, E., Cáceres, I., Huguet, R., Mosquera, M., Ollé, A., Rosell, J., Parés, J.M. Rodríguez, X.P., Díez, C., Rofes, J., Sala, R., Saladié, P., Vallverdú, J., Bennasar, M.L., Blasco, R., Bermúdez de Castro, J.M., Carbonell, E., 2011. One million years of cultural evolution in a stable environment at Atapuerca (Burgos, Spain). Quaternary Science Reviews 30 (11-12), 1396-1412.

Rodríguez-Hidalgo, A., Lloveras, L., Moreno-García, M., Saladié, P., Canals, A., Nadal, J., 2013. Feeding behaviour and taphonomic characterization of noningested rabbit remains produced by the Iberian lynx (Lynx pardinus). Journal of Archaeological Science 40, 3031-3045.

Roebroeks, W., 2001. Hominid behaviour and the earliest occupation of Europe: an exploration. Journal of Human Evolution 41, 437-461.

Roebroeks, W., 2006. The human colonisation of Europe: where are we? Journal of Quaternary Science 21 (5), 425-435.

Rofes, J., Cuenca-Bescós, G., 2006. First evidence of the Soricidae (Mammalia) Asoriculus gibberodon. (Petényi, 1864) in the Pleistocene of North Iberia. Rivista Italiana di Paleontologia e Stratigrafia 112 (2), 301-315.

Rofes, J., Cuenca-Bescós, G., 2009. First record of Beremendia fissidens (Mammalia,Soricidae) in the Pleistocene of the Iberian Peninsula, with a review of the biostratigraphy, biogeography and palaeoecology of the species. Comptes Rendus Palevol 8, 21-37.

Rofes, J., Cuenca-Bescós, G., 2011. Evolutionary history and biogeography of the genus Crocidura (Mammalia, Soricidae) in Europe, with emphasis on Crocidura kornfeldi. Mammalian Biology 76 (1), 64-78.

Rofes, J., Cuenca-Bescós, G., 2013. First record of Sorex (Drepanosorex) margaritodon (Mammalia,Soricidae) in Western Europe: biostratigraphy, biogeography and evolution of the species. Paläontologische Zeitschrift 87, 539-541.

Rofes, J., Cuenca-Bescós, G., Bennàsar, M., Blain, H.A., 2014. First record of the Sorex Runtonensis-subaraneus (Mammalia, Soricidae) group in the Iberian Peninsula. What's happening now in Atapuerca? Latest research at the Sierra de Atapuerca. In: XVII World UISPP Congress 2014 Burgos, 1-7 September. A2c: 56.

Rosas, A., Pérez-González, A., Carbonell, E., Van der Made, J., Sánchez-Marco, A., Laplana, C., Cuenca-Bescòs, G., Parés, J.M., Huguet, R., 2001. Le gisement pléistocene de la Sima del Elefante (Sierra de Atapuerca,Espagne). L'Anthropologie 105, 301-312.

Rosas, A., Huguet, R., Pérez González, A., Carbonell, E., Vallverdú, J., Van der Made, J., Allué, E., García, N., Pérez-Martínez, R., Rodríguez Méndez, J., Sala, R., Saladié, P. Simón, G., Martínez-Maza, C., Bastir, M., Sanchez, A., Parés, J.M., 2004. Iniatial approach to the site formation and paleoecology of the Sima del Elefante: a Pleistocene karst locality at Atapuerca Hill. In: Miscelánea en homenaje a Emiliano Aguirre. Geología. Alcalá de Henares, Museo Arqueológico Regional. Geología.

Rosas, A., Huguet, R., Pérez González, A., Carbonell, E., Bermúdez de Castro, J.M., Vallverdú, J., Van der Made, J., Allué, E., García, N., Pérez-Martínez, R., Rodríguez, J., Sala, R., Saladié, P., Benito, A., Martínez-Maza, C., Bastir, M., Sanchez, A., Parés, J.M., 2006. The Sima del Elefante cave site at Atapuerca (Spain). Estudios Geológicos 62 (1), 327-348.

Saladié, P., Huguet, Díez, C., Rodríguez-Hidalgo, A., Cáceres, I., Vallverdú, J., Rosell, J., Bermúdez de Castro, J.M., Carbonell, E., 2011. Carcass transport decisions in Homo antecessor subsistence strategies. Journal of Human Evolution 61, 425-446.

Saladié, P., Rodríguez-Hidalgo, A., Huguet, R., Cáceres, I., Díez, C., Vallverdú, J., Canals, A., Soto, M., Santander, B., Bermúdez de Castro, J.M., Arsuaga, J.L. Carbonell, E., 2014. The role of carnivores and their relationship to hominin settlements in the TD6-2 level from Gran Dolina (Sierra de Atapuerca, Spain). Quaternary Science Reviews 93, 47-66.

Sánchez Marco, A., 2002. Aves fósiles de la Península Ibérica. Quercus 191, 28-41.

Sánchez Marco, A., 2004. Avian zoogeographical patterns during the Quaternary in the Mediterranean region and paleoclimatic interpretation. Ardeola 5 (1), 90-132.

Southern, H.N., 1954. Tawny owls and their prey. Ibis 96, 348-410.

Stock, G.M., Anderson, R.S., Finkel, R.C., 2004. Pace of landscape evolution in the Sierra Nevada, California, revealed by cosmogenic dating of cave sediments. Geology 32, 193-196.

Toro-Moyano, I., Martínez-Navarro, B., Agustí, J., Souday, C., Bermúdez de Castro, J.M., Martinón-Torres, M., Fajardo, B., Duval, M., Falguères, C., Oms, O. Parés, J.M., Anadón, P., Julià, R., García-Aguilar, J.M., Moigne, A.M. Espigares, M.P., Ros-Montoya, S., Palmqvist, P., 2013. The oldest human fossil in Europe, from Orce (Spain). Journal of Human Evolution 65 (1), 1-9.

Vallverdú, J., Saladié, P., Rosas, A., Huguet, R., Cáceres, I., Mosquera, M., GarciaTabernero, A., Estalrrich, A., Lozano-Fernández, I., Pineda-Alcalá, A., Carrancho, A., Villalaín, J.J., Bourlès, D., Braucher, R., Lebatard, A., Vilalta, J. Esteban-Nadal, M., Bennàsar, M., Bastir, M., López-Polín, L., Ollé, A., Vergés, J.M., Ros-Montoya, S., Martínez-Navarro, B., García, J., Martinell, A., Expósito, I., Burjachs, F., Agustí, J., Carbonell, E., 2014. Age and Date for Early Arrival of the Acheulian in Europe (Barranc de la Boella, la Canonja, Spain). PLoS One e103634. http://dx.doi.org/10.1371/journal.pone.0103634.

Van der Made, J., 2013. First description of the large mammals from the locality of Penal, and updated faunal lists for the Atapuerca ungulates- Equus altidens, 
Bison and human dispersal into Western Europe. Quaternary International 295, $36-47$.

Van der Made, J., Aguirre, E., Bastir, M., Fernández-Jalvo, Y., Huguet, R., Laplana, C., Márquez-Mora, B., Martínez, C., Martinón, M., Rosas, A., Rodríguez, J. Sànchez, A., Sarmiento, S., Bermúdez de Castro, J.M., 2003. El registro paleontológico y arqueológico de los yacimientos de la Trinchera del Ferrocarril en la Sierra de Atapuerca. Coloquios de Paleontología Ext. 1, 345-372.

Villafuerte, R., 2007. In: Palomo, L.J., Gisbert, J., Blanco, J.C. (Eds.), Oryctolagus cuniculus (Linnaeus, 1758) Atlas y Libro Rojo de los Mamíferos Terrestres de España. Ministerio de Medio Ambiente, Madrid, p. 586. 